\title{
The planktonic Cladocera (Crustacea) and aspects of the eutrophication of Americana Reservoir, Brazil
}

\author{
MARLENE SOFIA ARCIFA ZAGO
}

\begin{abstract}
A B S T R A C T
This work refers to studies carried on Americana Reservoir, 22 ${ }^{\circ} 44^{\prime} 20^{\prime \prime} \mathrm{S}$ and 44'19'22" W, from June, 1969, to April, 1972. This reservoir is formed by a dam impounding the Atibaia River, which receives untreated domestic and industrial sewage.

Samplings were done at intervals of 30 to $\mathbf{5 0}$ days, at three stations. Plankton samples were taken with vertical net hauls. Parallel determinations were made of physical, chemical, and bacteriological factors.

Ten species of planktonic Cladocera were found: Daphnia gessneri, Ceriodaphnia cornuta, Ceriodaphnia reticulata, Moina cf. dubia, Moina sp., Diaphanosoma sp., Diaphanosoma neotropicum, Bosminopsis deitersi, Bosmina longirostris, and Eubosmina or Neobosmina sp. Their populations were estimated at the three stations. In the course of the three years were observed: increase in the concentrations of inorganic $\mathrm{N}$ and $\mathrm{P}$ that would indicate a sensible eutrophication; decrease in bottom DO values; small changes in transparency, BOD, superficial DO, and coliform bacteria numbers; short-term thermal stratification. Concerning the Cladocera, both the number of species and population densities decreased, what could have been influenced by shifts in trophic conditions or more probably, by toxic substances including the herbicide $2,4 \mathrm{D}$.
\end{abstract}

\section{RES UMO}

Este trabalho refere-se a estudos levados a efeito na Represa de Americana,

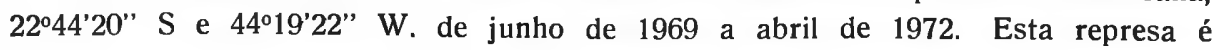
formada pelo represamento do Rio Atibaia, o qual recebe esgoto doméstico e industrial não sujeito a tratamento.

As coletas foram feitas a intervalos de 30 a 40 dias, em três estações. As amostras de plâncton foram obtidas com rede, através de puxadas verticais. Paralelamente foram feitas determinações de fatores físicos, químicos e bacteriológicos. 
Foram encontradas dez espécies de Cladocera: Daphnia gessneri, Ceriodaphnia cornuta, Ceriodaphnia reticulata, Moina cf. dubia, Moina sp., Diaphanosoma sp., Diaphanosoma neotropicum, Bosminopsis deitersi, Bosmina longirostris, and Eubosmina or Neobosmina sp. As populações dessas espécies foram estimadas nas três estações. No decorrer dos três anos foram observados: aumento das concentrações de $\mathrm{N}$ e $\mathrm{P}$ inorgânicos $\mathrm{o}$ que indicaria uma sensível eutrofização; queda dos teores de OD no fundo; pequenas modificações da transparência, do número de bactérias coliformes, da DBO e do OD superficial; estratificações térmicas de curta duração. Quanto aos Cladocera, houve redução do número de espécies e das densidades populacionais, o que pode ter sido influenciado pelas alterações das condições tróficas ou mais provavelmente, por substâncias tóxicas inclusive o herbicida 2,4 D.

\section{N T R O D U C T I O N}

Eutrophication is a problem that is being intensely studied, mainly in temperate regions. In tropical ones researches are scarce, and in Brazil they are being developed allied to those on the sanitary conditions of the water (Branco, 1966; Azevedo et al., 1967; Kawai and Branco, 1969; Kawai et al., 1972).

However, the existing papers refer in general only to short periods of time and there are no data on long-term development of the water bodies.

This work is part of a prolonged survey program in Americana Reservoir, started in 1969, which is being carried on with the cooperation of the state organization for sanitation - CETESB (Companhia Estadual de Tecnologia de Saneamento Básico e de Controle de Poluição das Águas). In this work an analysis is done of the variations of the planktonic Cladocera populations, from June, 1969, to April, 1972.

Americana Reservoir was built in 1949, and is located in Americana Municipality, in São Paulo State, Brazil, 22 $44^{\prime} 20^{\prime \prime}$ S Latitude and $44^{\circ} 19^{\prime} 52^{\prime}$ "W Longitude. Its area is $11.50 \mathrm{~km}^{2}$, the length of the shoreline $64 \mathrm{~km}$ and the length $17 \mathrm{~km}$. The maximum storage is $102,000,000 \mathrm{~m}^{3}$, the detention time about 56 days. The depth is very variable, with a maximum of $19 \mathrm{~m}$ and $9 \mathrm{~m}$ on the average. It is formed by Atibaia River, impounded by Salto Grande Dam and is utilized for several purposes: water and electrical energy supplies and recreation.

Upstream of Paulinia, the nearest town to the reservoir, Atibaia River receives Pinheiros and Anhumas Streams, which receive domestic and industrial sewage from Valinhos and Campinas, and the wastes of a chemical industry-Rhodia S/A. According to Rocha and al. (1971 and 1972) these are the major sources of pollution. Since January, 1972, the river is also receiving wastes from an oil refinery. Other pollution sources of less importance comprise small farms, sugar cane and cattle farms, clubs and countryhouses, located along the edge of this water body. 


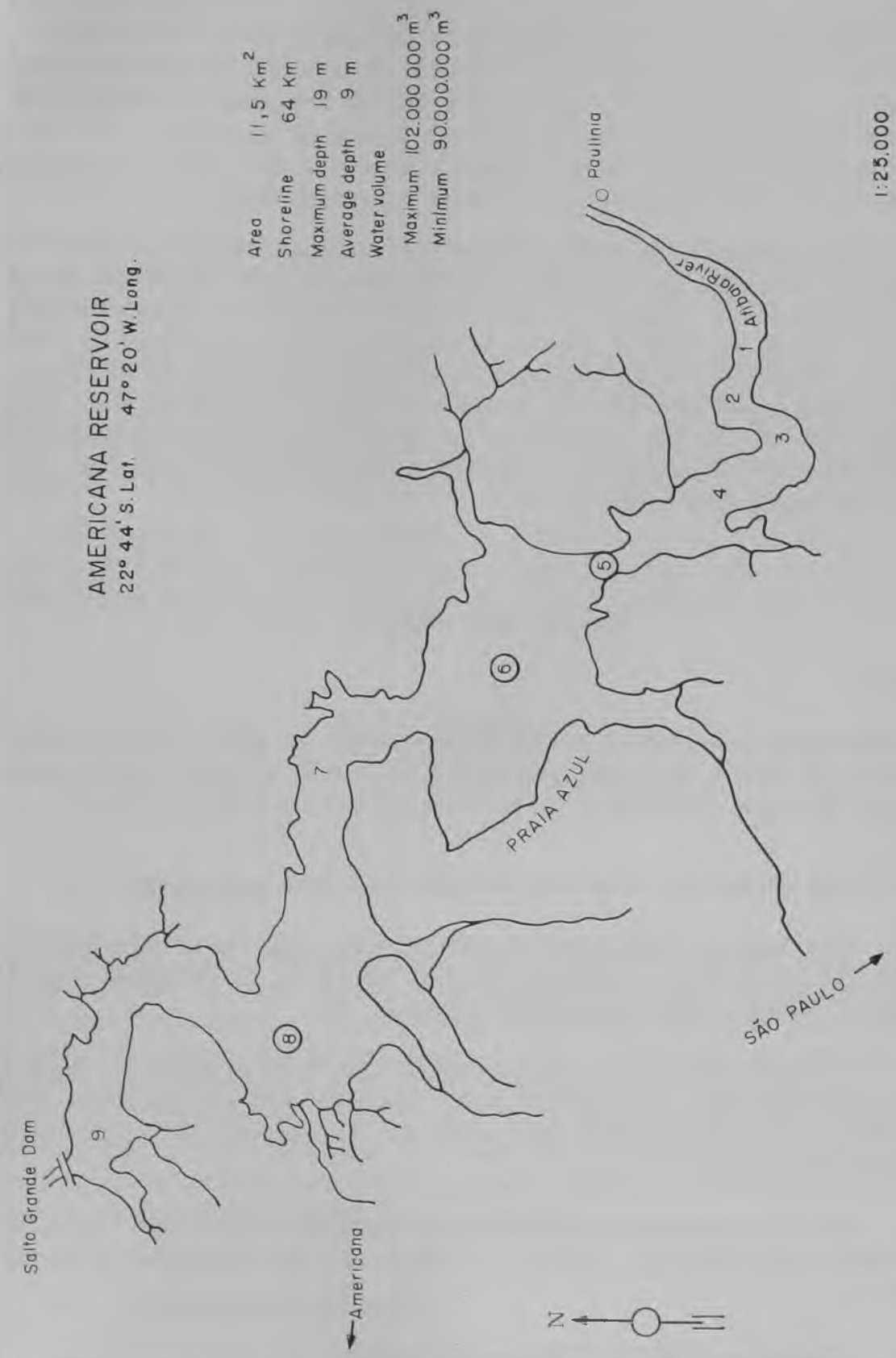


During the period considered here, there occurred a water bloom of the blue-green alga Anabaena spiroides in September, 1969, a flooding in January, 1970, and two treatment periods against Eichhornia crassipes with 2,4 D. The first, from January to February, 1970, was intensive, with air and motor-boat spraying of the herbicide, while the second, from July, 1971, to August, 1972, was established as a permanent service, the herbicide being sprayed from motor-boats whenever necessary. The upstream portions of the reservoir, including Station 5, were more intensively treated due to the rich growths of water hyacinths there.

I wish to express my acknowledgements to Dr. Claudio G. Froehlich for general advising; to Dr. Hans Volkmar Herbst for determination of the Cladocera; to Dr. Tagea K. S. Björnberg for her interest and encouragement; to Márcia N. Cipolli, Maria Apparecida Juliano de Carvalho, and Fernando Frassei for technical assistance; to the CETESB for the laboratory analyses and specially to Aristides A. Rocha for various help; and to Shirley Bruno for typing the MS. My special thanks are also extended to the FAPESP (Fundação de Amparo à Pesquisa do Estado de São Paulo) for equipment granted.

\section{Material and Methods}

\section{Sampling}

Samplings were carried out from June, 1969, to April, 1972, at three stations (5,6, and 8 , see map), between 9 a.m. and 13 p.m., at intervals of 30 to 50 days.

At each station the following samples and data were taken:

a. Plankton - three samples colleted with a $25 \mathrm{~cm}$ mouth-diameter and $85 \mu \mathrm{m}$ meshed net, through vertical hauls at ca. constant speed. Immediate fixation with neutralized formalin $4 \%$.

b. Temperature of the air, superficial and bottom water - with a mercury thermometer. For bottom water temperatures, samples were collected with a Kemmerer bottle into which the thermometer was introduced just after opening it.

c. $\mathrm{pH}$ of superficial and bottom water-with indicator paper Panpeha, from Riedel de Häen Ag, Seelze - Hannover, and Metrohm pHmeter E $280 \mathrm{~A}$.

d. Colour - with the Forel - Ule scale.

e. Transparency - with a Secchi disc $30 \mathrm{~cm}$ in diameter. 
f. Water samples for determinations of: DO, BOD, ammonia, nitrite, nitrate, phosphate, chlorophyll, and coliform bacteria.

Chemical and bacteriological analyses were carried out according to methods found in "Standard Methods for the Examination of Water and Wastewater" (1965 and 1971).

\section{Counting}

The volumes of plankton of the three samples from each station were compared, one or more samples being counted depending on the likeness between them.

Samples were submitted to total counting or subsample methods, depending on the volume of plankton. For subsampling, a $1 \mathrm{ml}$ Stempel Pipette (Schwoerbel, 1966) or a Petri dish $8,7 \mathrm{~cm}$ in diameter, divided into 8 parts were used. From the Petri dish one or more fields were counted. The number of specimens counted varied from 100 to 300 .

The period from June, 1969, to April, 1972, was divided in three years, as follows: $1^{\text {st }}$ year-from June, 1969 , to May, $1970 ; 2^{\text {nd }}$ year-from June, 1970, to May, 1971; $3^{\text {rd }}$ year-from June, 1971, to April, 1972.

\section{Results}

Physical, chemical and bacteriological conditions.

\section{a. Temperature}

Surface water temperatures varied between $18.5^{\circ} \mathrm{C}$ and $31.5^{\circ} \mathrm{C}$ (Fig. 1, Tab. 1), and usually were higher than those of bottom waters. In several occasions, relatively large differences were recorded between surface and depth, the largest being $4.9^{\circ} \mathrm{C}$. A thermal stratification frequently coincided with calm weather or slight breezes and higher temperatures. Seldom the bottom water was warmer than the surface one. Kleerekoper (1939) recorded the same phenomenon from Santo Amaro (Guarapiranga) Reservoir, and suggested that it could be due to a warm current or to intense fermentative processes.

\section{b. Colour and transparency}

The colour varied from greenish to brown, corresponding to numbers 15 to 20 in the Forel-Ule scale; more often colours 16 and 17 were recorded. 

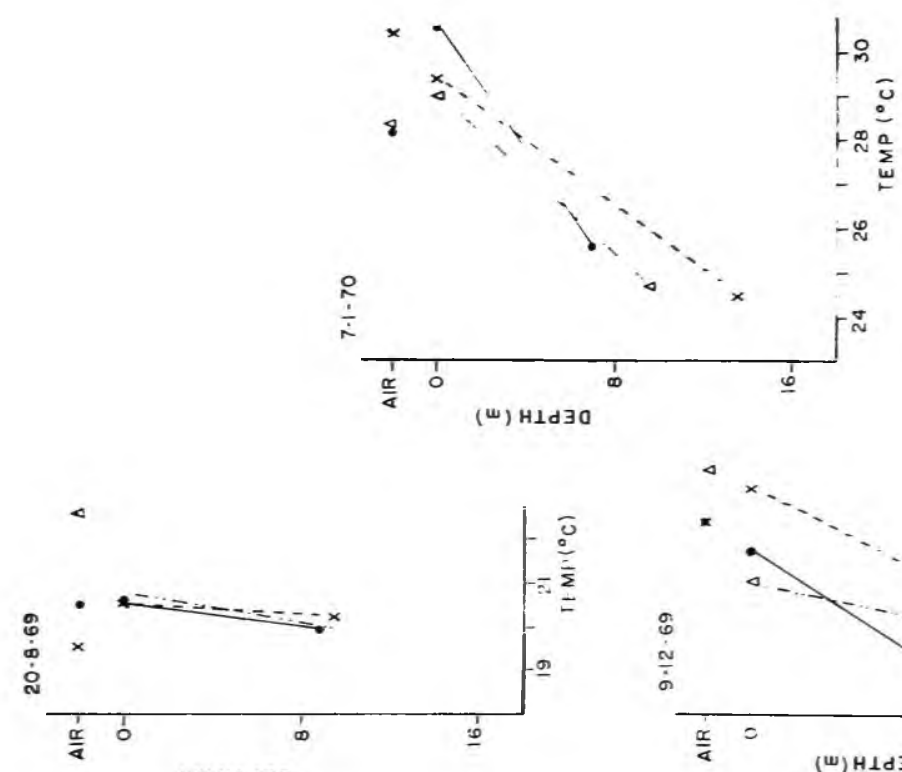

(4) $H \perp d \exists O$
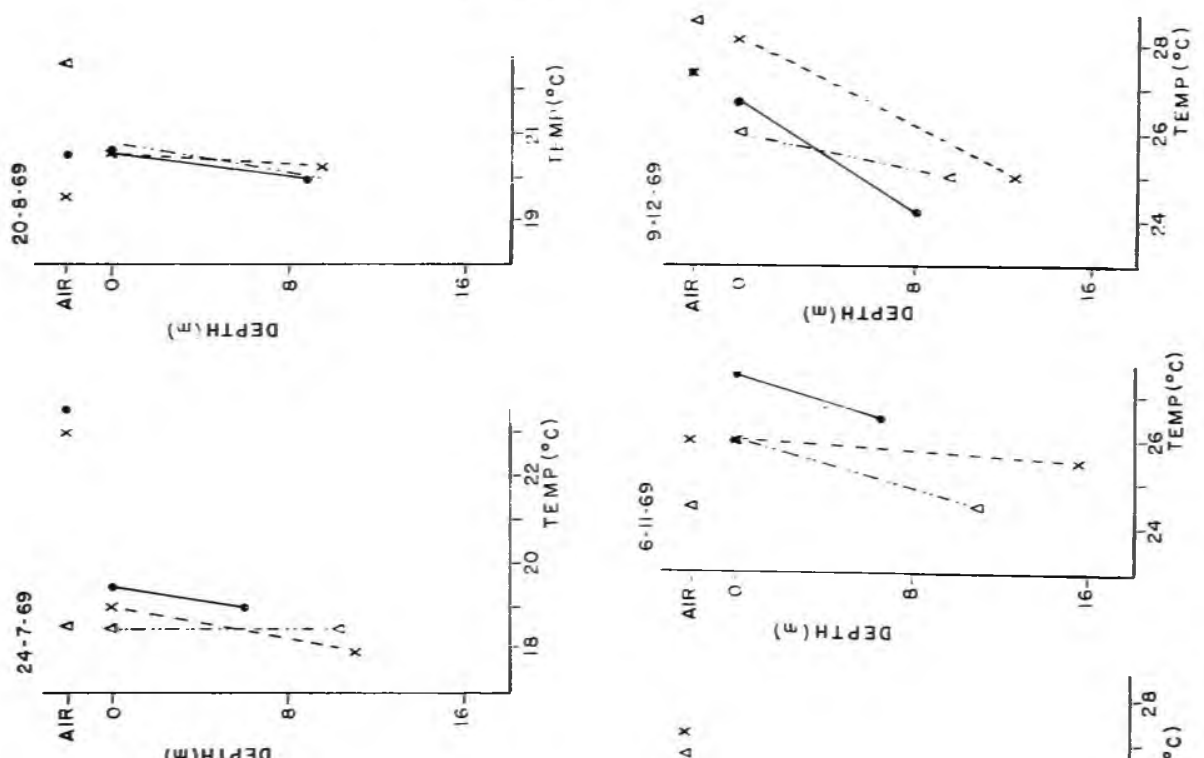

(w) H 1 d 30

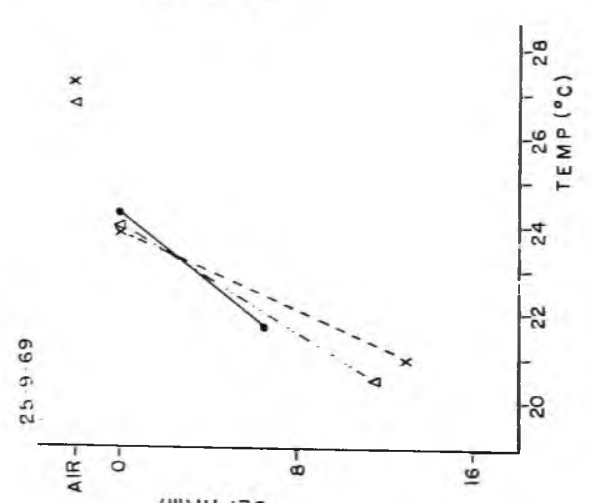

(w) $H 1 d 30$

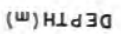

Fig. 1-A 

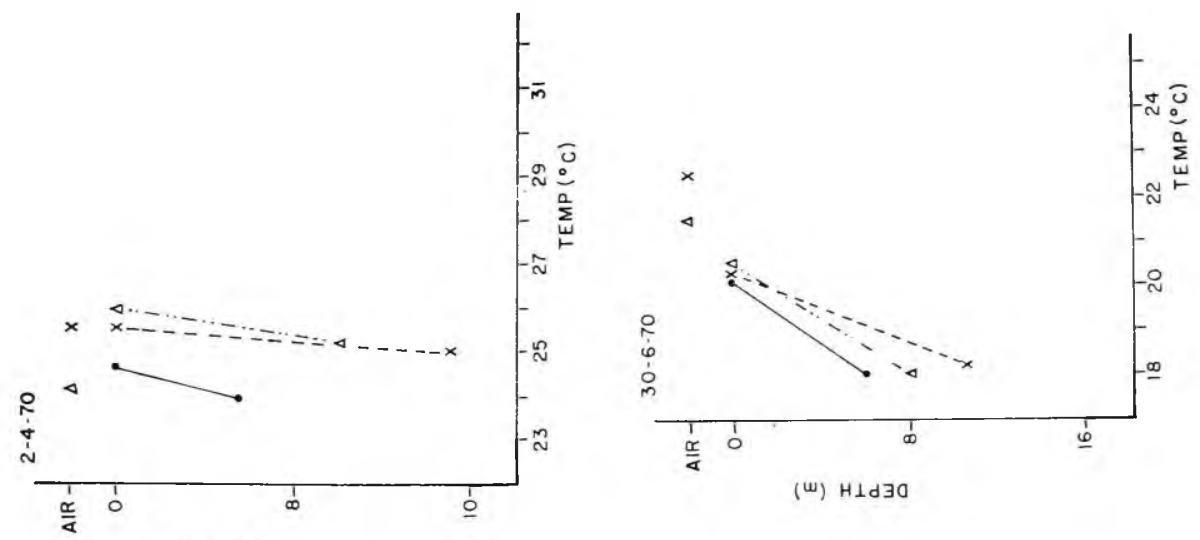

(w) $\mathrm{H} \perp \mathrm{d} \exists \mathrm{O}$
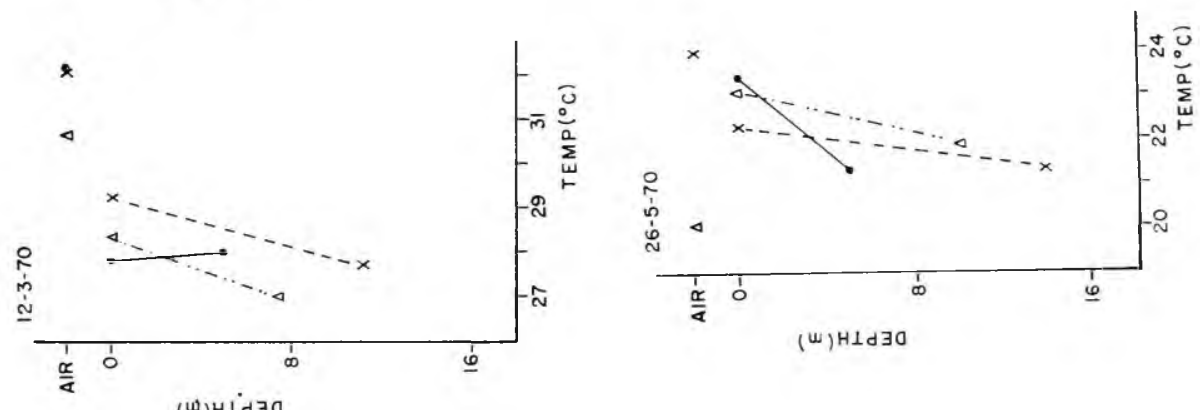

(w) $H \perp d \exists a$
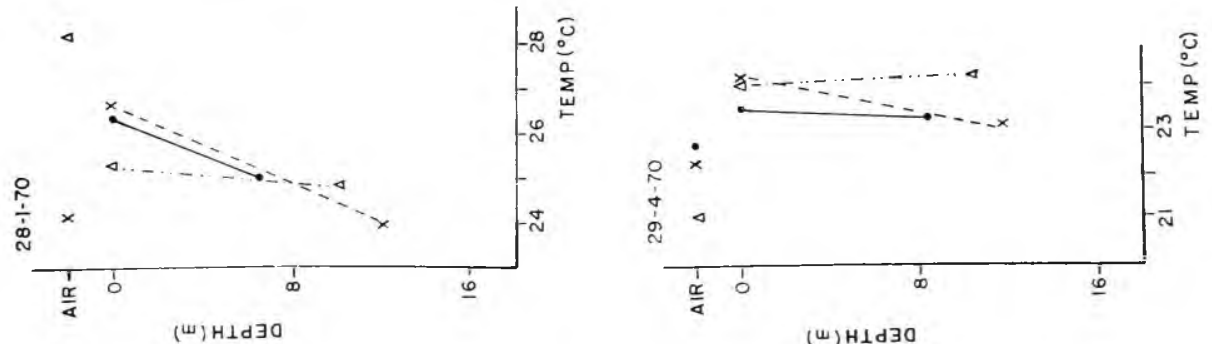

Fig. 1-B 


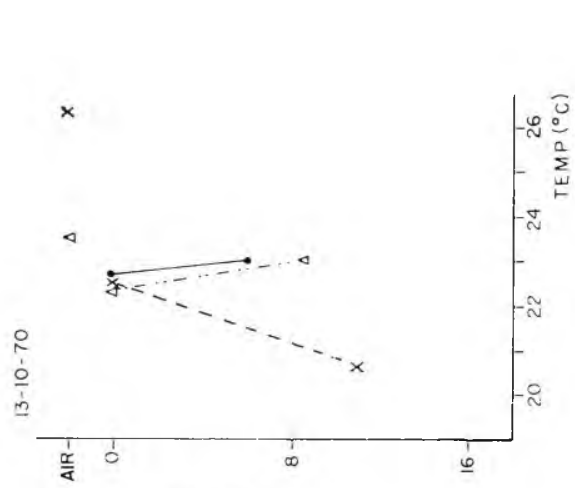

(w) $H \perp d \exists O$
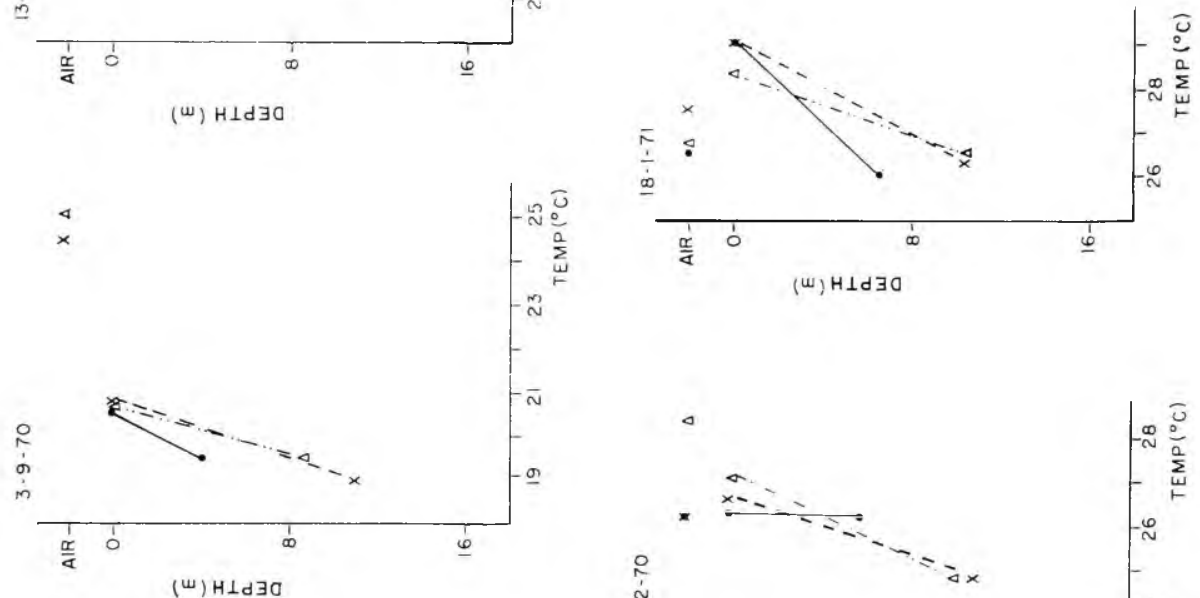

(w) $H \perp d 30$
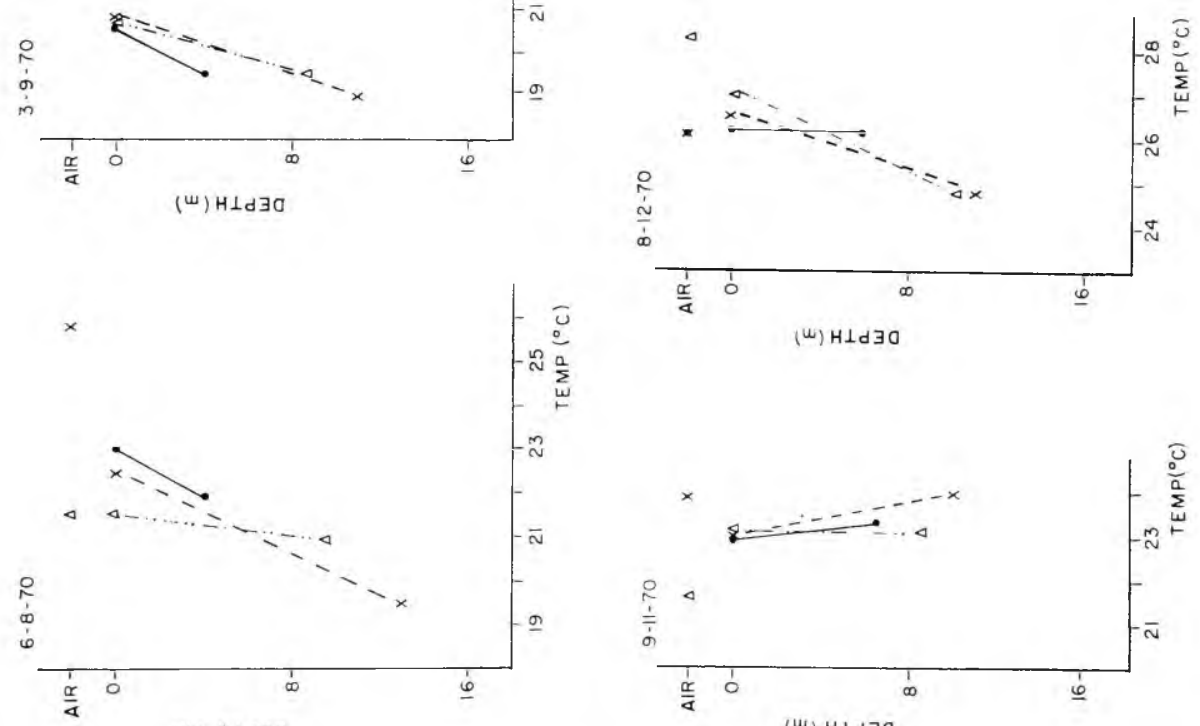

(w) $\mathrm{H} \perp \mathrm{dO}$

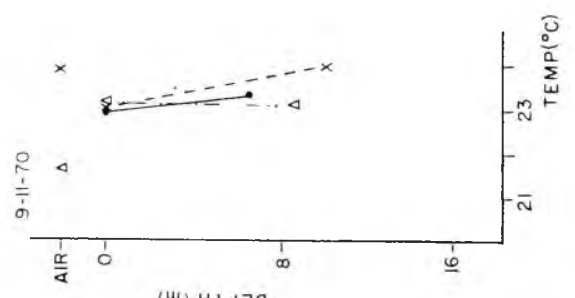

(w) $\operatorname{H} \perp \exists \mathrm{O}$

Fig. 1-C 

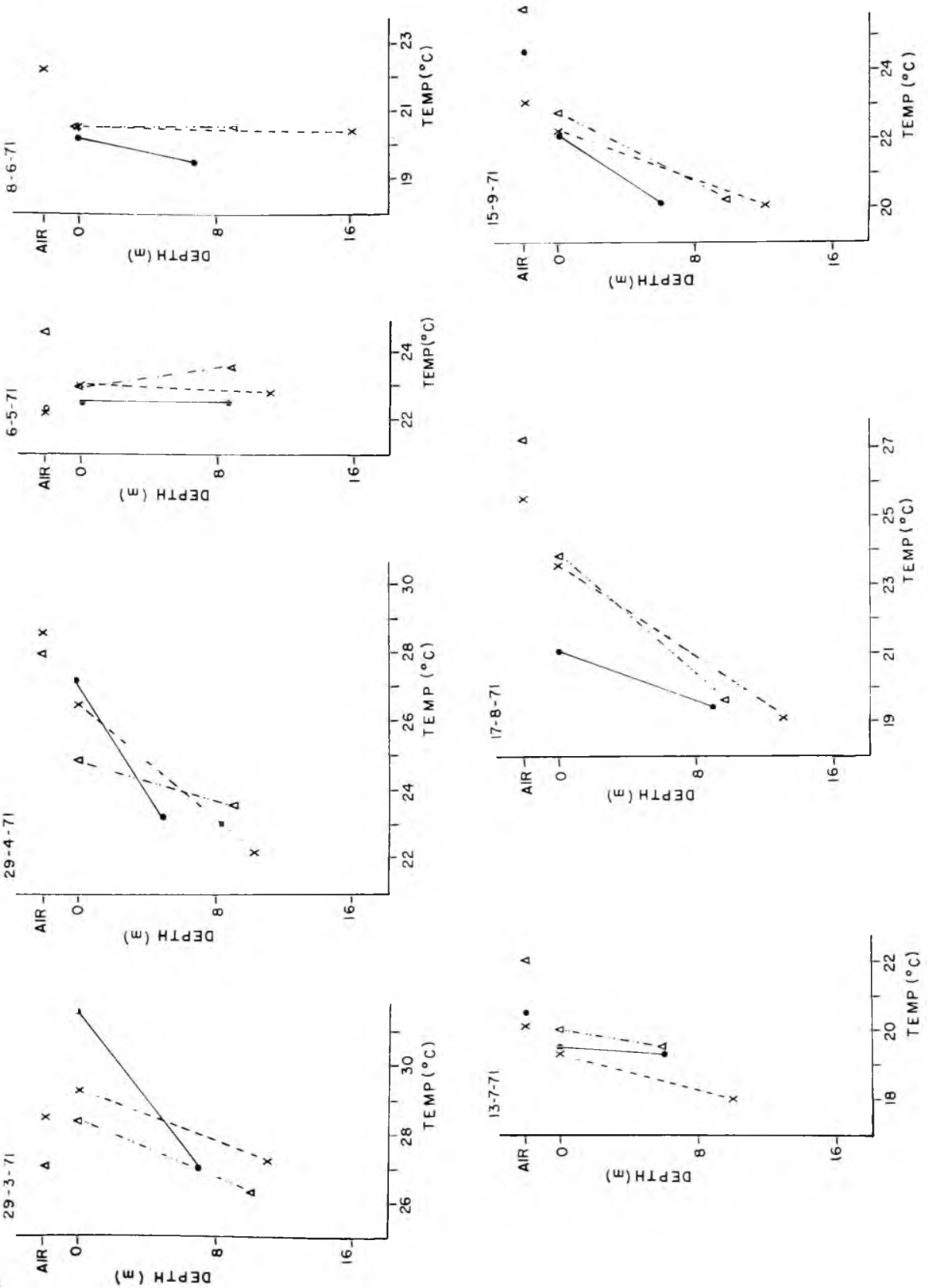

(w) $\mathrm{H} \perp \mathrm{d} 3 \mathrm{O}$

Fig. 1-D 

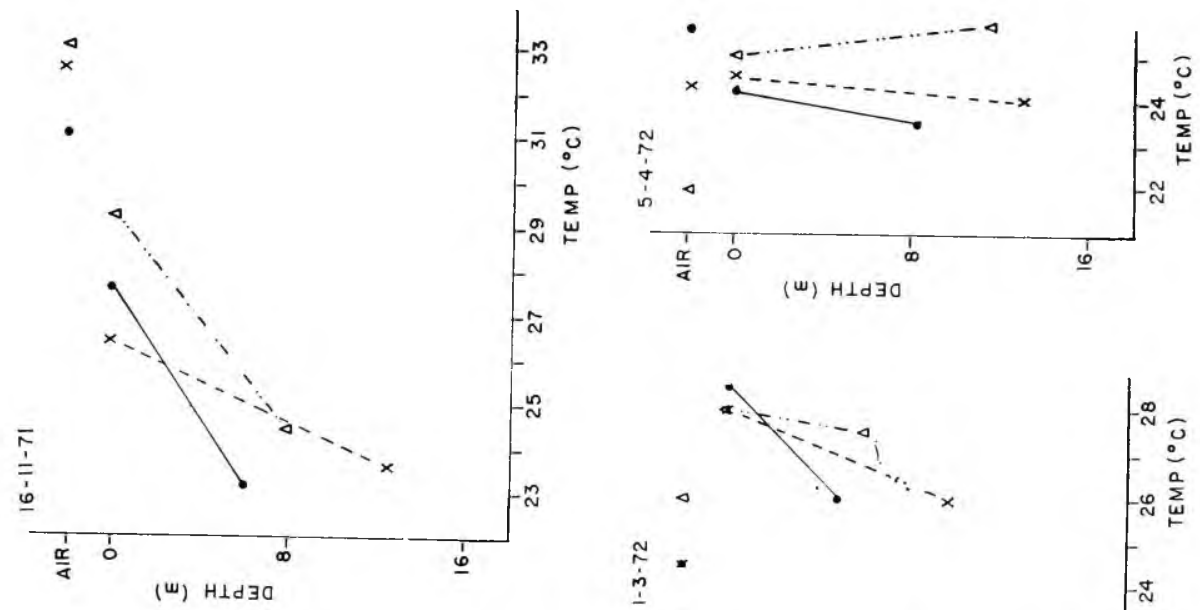

(w) $H \perp d \exists O$

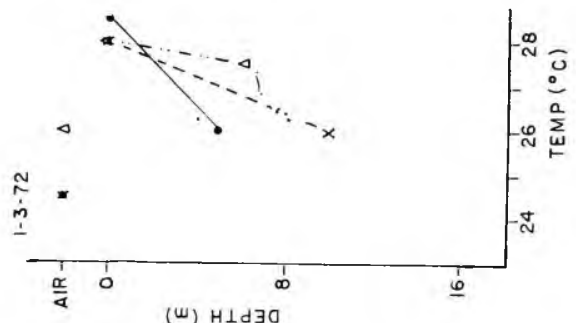

(w) $H \perp d \exists O$

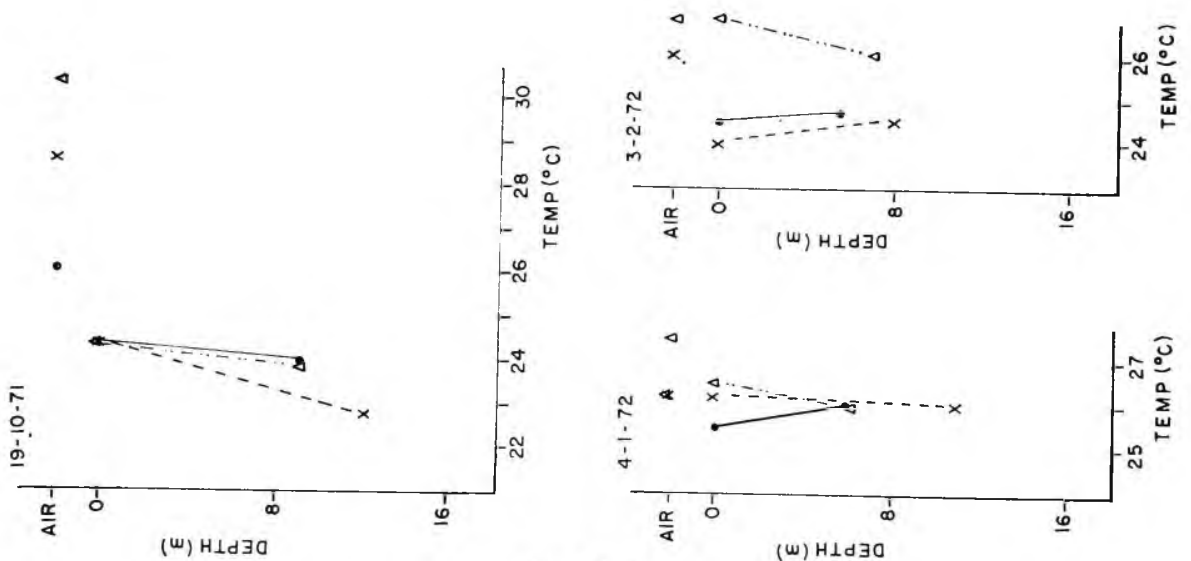

Fig. 1-E

Fig. 1 A-E - Air, superficial and bottom water temperatures $\left({ }^{\circ} \mathrm{C}\right)$, at the three stations, from June 1969 to April 1972.

St. 5

$x----x$ St. 6

$\triangle-\cdots-\triangle$

St. 8 
TABLE 1 -Air, superficial and bottom water temperatures $\left({ }^{\circ} \mathrm{C}\right)$, at the three stations, from June 1969 to April 1972.

\begin{tabular}{|c|c|c|c|c|c|c|c|c|c|}
\hline \multirow[b]{2}{*}{ Date } & \multicolumn{3}{|c|}{ St } & \multicolumn{3}{|c|}{ St 6} & \multicolumn{3}{|c|}{ St 8} \\
\hline & Air & Sup. & Bottom & Air & Sup. & Bottom & Air & Sup.. & Bottom \\
\hline $5 / 06 / 69$ & 24.6 & 21.0 & - & 23.9 & 20.8 & 20.7 & 20.2 & 20.3 & 20.7 \\
\hline $24 / 07 / 69$ & 23.5 & 19.5 & 19.0 & 23.0 & 19.0 & 1 & 5 & 18.5 & 18.5 \\
\hline $20 / 08 / 69$ & 20.5 & 20.5 & 19.9 & 19.5 & 20.5 & 20.2 & 0 & .7 & .8 \\
\hline $25 / 09 / 69$ & 28.2 & 24.3 & 21.7 & 27.3 & 23.9 & 2 & 6.8 & 24.0 & 0.5 \\
\hline $06 / 11 / 69$ & 26.0 & 27.5 & 26.5 & 26.0 & 26.0 & 25.5 & 4.5 & 26.0 & 4.5 \\
\hline $09 / 12 / 69$ & 27.4 & 26.7 & 24.2 & 27.3 & 28.1 & 25.0 & 28.5 & 26.0 & 5.0 \\
\hline $07 / 01 / 70$ & 28.2 & 30.5 & 25.6 & 30.4 & 29.4 & 24.5 & 28.3 & 29.0 & 4.7 \\
\hline $28 / 01 / 70$ & 27.6 & 26.4 & 25.0 & 24.2 & 26.7 & 240 & 28.2 & 25.3 & 4.8 \\
\hline $12 / 03 / 70$ & 321 & 27.8 & 28.0 & 32.0 & 29.2 & 27.7 & 30.6 & 28.3 & 27.0 \\
\hline $02 / 04 / 70$ & 32.0 & 24.6 & 23.9 & 25.5 & 25.5 & 25.0 & 24.1 & 25.9 & 25.2 \\
\hline $29 / 04 / 70$ & 22.7 & 23.5 & 23.3 & 22.3 & 24.2 & 23.1 & 211 & 24.1 & 24.2 \\
\hline $26 / 05 / 70$ & 24.4 & 23.4 & 21.3 & 24.0 & 22.3 & 21.3 & 20.1 & 231 & 21.9 \\
\hline $30 / 06 / 70$ & 25.5 & 20.1 & 18.0 & 22.5 & 20.3 & 18.2 & 21.5 & 20.5 & 18.0 \\
\hline $06 / 08 / 70$ & 26.8 & 23.0 & 21.9 & 24.8 & 22.5 & 19.5 & 215 & 21.5 & 20.9 \\
\hline $03 / 09 / 70$ & 23.5 & 20.5 & 19.5 & 24.5 & 20.8 & 19.0 & 251 & 20.6 & 19.5 \\
\hline $13 / 10 / 70$ & 24.2 & 22.6 & 23.0 & 26.3 & 225 & 20.6 & 23.5 & 22.3 & 23.0 \\
\hline 0 & 24.6 & 22.9 & 23.3 & 23.9 & 23.0 & 24.0 & 21.6 & 23.1 & 23.1 \\
\hline $08 / 12 / 70$ & 26.1 & 26.2 & 26.1 & 26.1 & 265 & 248 & 28.3 & 27.0 & 24.8 \\
\hline $18 / 01 / 71$ & 26.5 & 29.0 & 260 & 275 & 290 & 26.3 & 267 & 28.5 & 26.5 \\
\hline $01 / 03 / 71$ & 232 & 25.6 & 24.3 & 24.4 & 26.4 & 259 & 25.5 & 26.2 & 25.5 \\
\hline $29 / 03 / 71$ & 275 & 315 & 270 & 28.4 & 29.2 & 272 & 27.0 & 28.3 & 26.3 \\
\hline $29 / 04 / 71$ & 30.2 & 262 & 232 & 28.6 & 25.5 & 222 & 28.0 & 24.9 & 23.6 \\
\hline $06 / 05 / 71$ & 22.3 & 225 & 225 & 22.2 & 23.0 & 22.8 & 24.5 & 23.0 & 23.5 \\
\hline $08 / 06 / 71$ & 23.1 & 20.2 & 195 & 22.2 & 20.5 & 20.4 & 22.2 & 20.5 & 205 \\
\hline $13 / 07 / 71$ & 20.5 & 19.5 & 19.3 & 20.1 & 19.3 & 18.0 & 22.0 & 20.0 & 195 \\
\hline $17 / 08 / 71$ & 24.5 & 21.0 & 19.4 & 25.5 & 23.5 & 19.1 & 27.2 & 23.8 & 19.6 \\
\hline $15 / 09 / 71$ & 4.5 & 22.1 & 201 & 23.0 & 22.2 & 20.0 & 25.7 & 227 & 20.2 \\
\hline $19 / 10 / 71$ & 26.0 & 24.3 & 23.3 & 28.5 & 24.3 & 22.7 & 30.3 & 24.3 & 23.8 \\
\hline $16 / 11 / 71$ & 31.0 & 27.6 & 23.1 & 32.5 & 26.4 & $23 . E$ & 33.0 & 29.2 & 24.4 \\
\hline $04 / 01 / 72$ & 25.5 & 25.5 & 26.0 & 26.2 & 26.2 & 26.0 & 275 & 26.5 & 26.0 \\
\hline $03 / 02 / 72$ & 26.0 & 24.5 & 24.7 & 26.0 & 24.0 & 24.5 & 268 & 26.8 & 260 \\
\hline $07 / 03 / 72$ & 24.5 & 28.5 & 26.0 & 24.5 & 28.0 & 26.0 & 26.0 & 28.0 & 27.5 \\
\hline $05 / 04 / 72$ & 25.6 & 24.2 & 23.5 & 24.3 & 24.5 & 24.0 & 22.0 & 25.0 & 25.7 \\
\hline
\end{tabular}


In general St. 5 had smaller transparencies, and St. 8 larger ones (Fig. 2, Tab. 2). The transparency shows a trend to decrease during summer, which is the rainy season, when the river carries much sediment, giving the water a muddy appearance. St. 5, being closer to the mouth of the river, is the most affected by the material in suspension brought in by the river.

The decrease in transparency which occurred at St. 6 in September, 1969, was caused by a water bloom of the blue-green alga Anabaena spiroides. On this occasion the smallest transparency was recorded from St. 8, where the phytoplankton was most abundant.

The averages indicate a small decrease in transparency from the first to the third year, with an increase in the second year (Tab. 3).

\section{c. $\mathrm{pH}$ and alkalinity}

As measured with the indicator paper, the $\mathrm{pH}$ varied between 5.5 and 6.5 , being usually around 6 . This method is not sensitive enough to detect small differences between vertical and temporal distributions. In August and September, 1970, an electronic pHmeter was employed. The values ranged from 6.1 to 7.6 , being higher at the surface.

Eight alkalinity determinations were made, 6 in 1971 and 2 in 1972. The values, expressed as $\mathrm{HCO}_{3}{ }^{-}$, varied between 13 and $35 \mathrm{mg} / \mathrm{l}$, with an average of $25 \mathrm{mg} / \mathrm{l}$.

d. Dissolved oxygen (DO) and biochemical oxygen demand (BOD).

At the surface, DO values varied from 2.20 to $13.80 \mathrm{mg} / \mathrm{l}$, corresponding respectively to 27.46 and 195.46 per cent saturation (Fig. 3, Tab. 4). At the bottom, zero and $1040 \mathrm{mg} / \mathrm{l}$ were the limits, corresponding to zero and 137.38 per cent saturation.

The superficial DO peaks generally matched the chlorophyll peaks, or at least occurred when the latter presented average values (Fig. 9). The bottom DO curves of the first samples of the second year were close to those of superficial DO. In the third year, however, they were often much apart, with a marked fall of the bottom DO values.

Periods of DO stratification were not always coincident with periods of thermal stratification.

On March 29, 1971, at St. 5 the DO value was larger at the bottom than at the surface. Branco (1966) noticed the same condition in Billings Reservoir, considering it as an indication of total circulation, with a temporary inversion of surface and bottom layers.

The average values presented in Tab. 5 show increasing surface DO values from St. 5 to $\mathrm{St}$. 8 . The same ocurred with the bottom DO in 


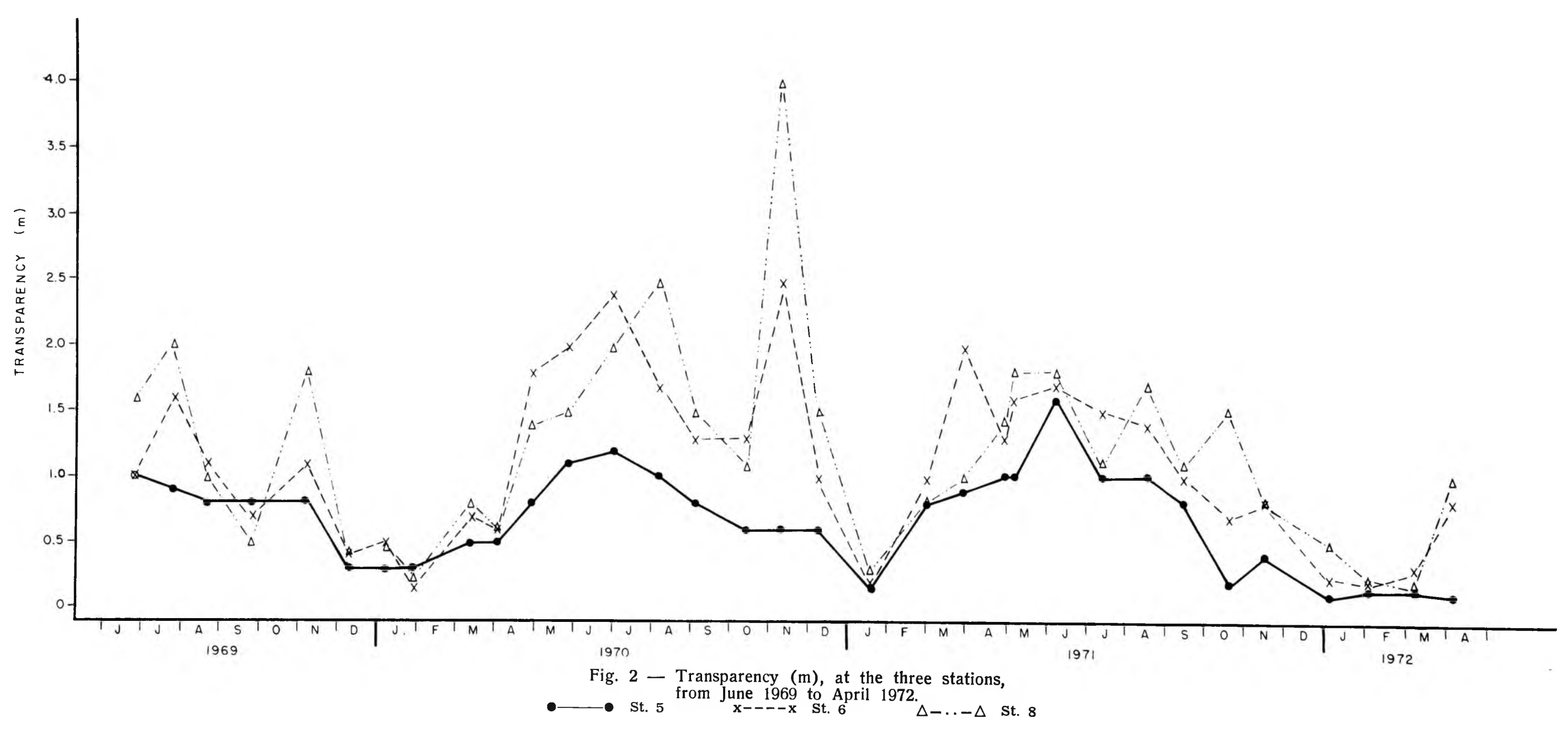



TABLE 2 - Transparency (m), at the three stations, from June 1969 to April 1972.

\begin{tabular}{|c|c|c|c|}
\hline Data & St. 5 & St. 6 & St. 8 \\
\hline $25 / 06 / 69$ & 1.00 & 1.00 & 160 \\
\hline $24 / 07 / 69$ & 090 & 160 & 200 \\
\hline $20 / 08 / 69$ & 0.80 & 110 & 1.00 \\
\hline $25 / 09 / 69$ & 080 & 070 & 050 \\
\hline $06 / 11 / 69$ & 080 & 110 & 180 \\
\hline $09 / 12 / 69$ & 030 & 0.40 & 040 \\
\hline $07 / 01 / 70$ & 0.30 & 0.50 & 050 \\
\hline $28 / 01 / 70$ & 0.30 & $0 \quad 15$ & 0.25 \\
\hline $12 / 03 / 70$ & $0 \quad 50$ & 070 & 080 \\
\hline $02 / 04 / 70$ & 050 & 060 & 0.60 \\
\hline $29 / 04 / 70$ & 0.80 & 180 & 140 \\
\hline $26 / 05 / 70$ & 110 & 2.00 & 150 \\
\hline $30 / 06 / 70$ & 120 & 2.40 & 200 \\
\hline $06 / 08 / 70$ & 100 & 160 & 250 \\
\hline $03 / 09 / 70$ & 080 & 120 & 150 \\
\hline $13 / 10 / 70$ & 0.60 & 120 & 110 \\
\hline $09 / 11 / 70$ & 060 & 250 & 4.00 \\
\hline $08 / 12 / 70$ & 060 & 1.00 & 150 \\
\hline $18 / 01 / 71$ & $0 \quad 15$ & 020 & 0.30 \\
\hline $01 / 03 / 71$ & 080 & 1.00 & 0.80 \\
\hline $29 / 03 / 71$ & 0.90 & 2.00 & 100 \\
\hline $29 / 04 / 71$ & 1.00 & 130 & 140 \\
\hline $06 / 05 / 71$ & 100 & 1.60 & 180 \\
\hline $08 / 06 / 71$ & 160 & 170 & 180 \\
\hline $13 / 07 / 71$ & 100 & 150 & 110 \\
\hline $17 / 08 / 71$ & 1.00 & 1.40 & 170 \\
\hline $15 / 09 / 71$ & 080 & 1.00 & 110 \\
\hline $19 / 10 / 71$ & 0.20 & 0.70 & 150 \\
\hline $16 / 11 / 71$ & 040 & 080 & 080 \\
\hline $04 / 01 / 72$ & 0.10 & 0.25 & 050 \\
\hline $03 / 02 / 72$ & $0 \quad 15$ & 0.20 & $0 \quad 25$ \\
\hline $07 / 03 / 72$ & $0 \quad 15$ & $0 \quad 30$ & 020 \\
\hline $05 / 04 / 72$ & 010 & 080 & 1.00 \\
\hline
\end{tabular}


TABLE 3 - Average values of transparency, BOD, ammonia, nitrite, nitrate, at each station in the three years.

\begin{tabular}{|c|c|c|c|c|c|}
\hline \multicolumn{2}{|c|}{ Period } & St. 5 & St. 6 & St. 8 & \multirow[t]{2}{*}{ Total average } \\
\hline \multicolumn{5}{|c|}{ Transparency (m) } & \\
\hline June/69 & - May/70 & 0.67 & 0.97 & 1.03 & 0.89 \\
\hline June/70 & - May/71 & 0.79 & 1.45 & 1.63 & 1.29 \\
\hline June/ 71 & -April/72 & 0.55 & 0.86 & 0.99 & 0.80 \\
\hline \multicolumn{6}{|c|}{ E O D ( ngg/l) } \\
\hline June/69 & May $/ 70$ & 4.45 & 3.98 & 3.67 & 4.03 \\
\hline June/70 & May/7I & 3.21 & 3.70 & .3 .51 & 3.47 \\
\hline June/71 & -April/72 & 3.09 & 3.25 & 3.44 & 3.26 \\
\hline \multicolumn{6}{|c|}{ Ammonia (mg/l) } \\
\hline June/69 & - May/70 & 0.283 & 0.189 & 0.129 & 0.200 \\
\hline June/70 & - May/71 & 0.360 & 0.280 & 0.116 & 0.252 \\
\hline June/7 1 & -April/72 & 0.440 & 0189 & 0.169 & 0.266 \\
\hline \multicolumn{6}{|c|}{ Nitrite (mg/l) } \\
\hline June/69 & - May/70 & 0.0220 & 0.0220 & 0.0210 & 0.0217 \\
\hline June/70 & - May/71 & 0.3015 & 0.2950. & 0.3825 & 0.3263 \\
\hline June/71 & -April/72 & $0 \quad 0771$ & 0.1200 & 0.0386 & 0.0786 \\
\hline \multicolumn{6}{|c|}{ Nitrate $(\mathrm{mg} / 1)$} \\
\hline June/69 & - May/70 & 0.283 & $0 \quad 274$ & 0.357 & 0.304 \\
\hline June/70 & - May/71 & 0.311 & 0.218 & 0.290 & 0.273 \\
\hline June/71 & - April/72 & 0.524 & 0.604 & 0.403 & 0.510 \\
\hline
\end{tabular}





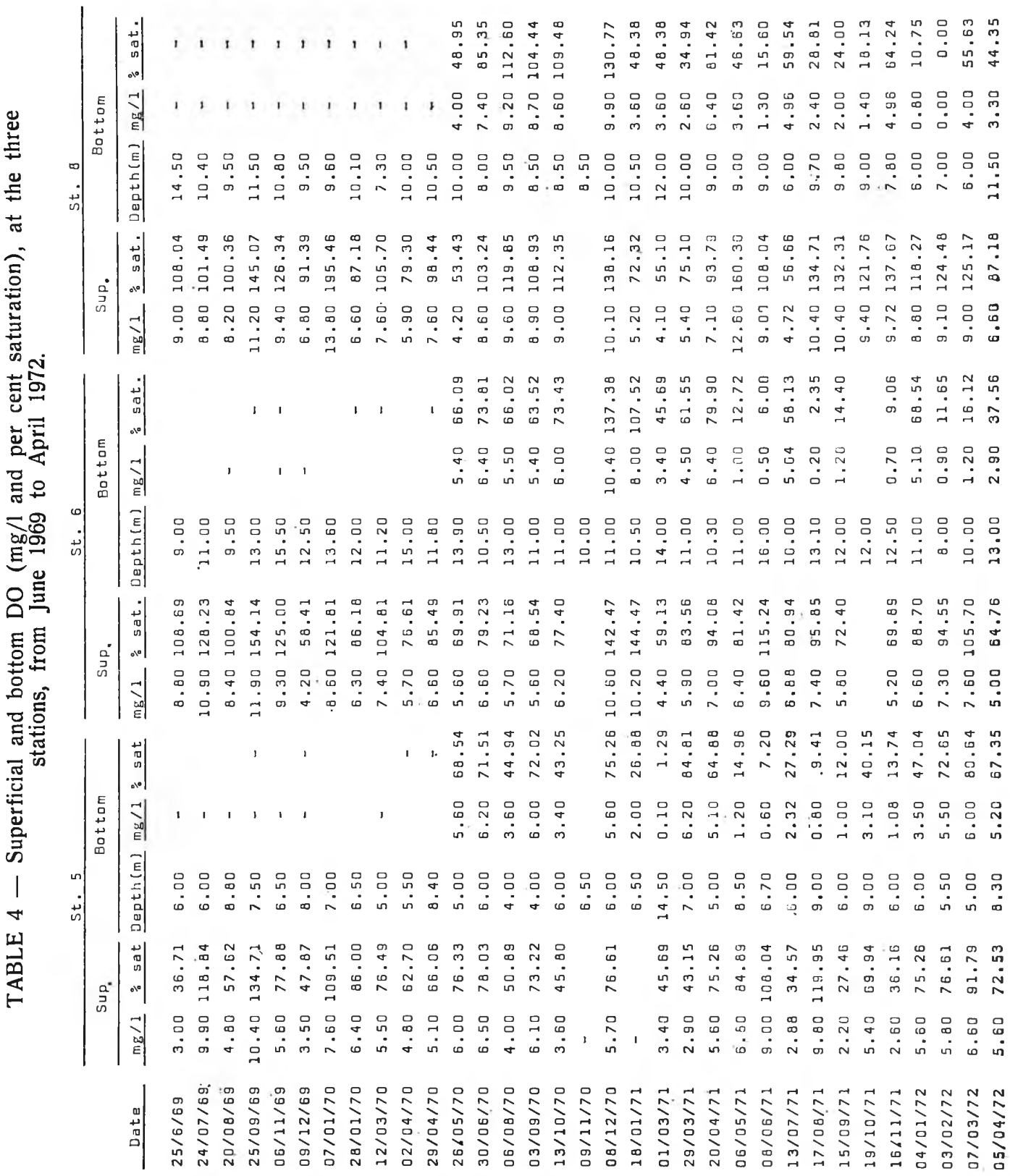




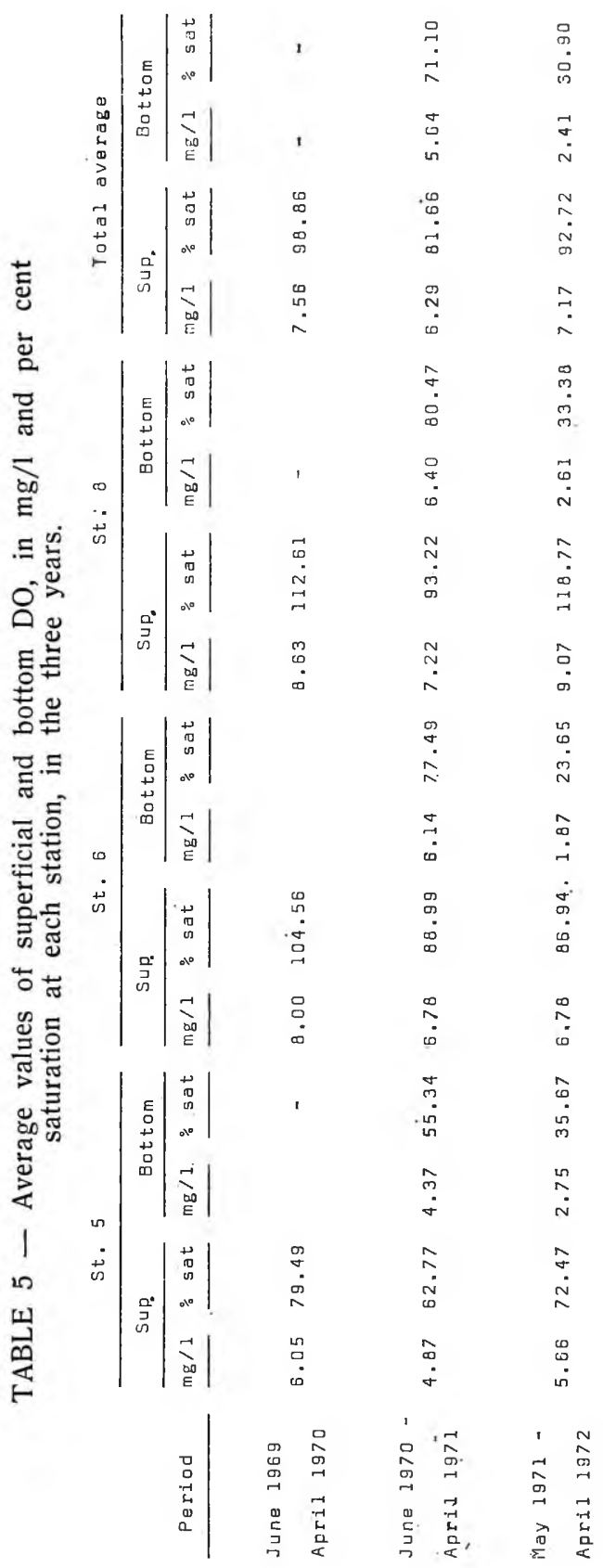


the second year, but in the third St. 5 presented slightly larger values. The general average values of surface DO diminished a little during the second year, while bottom DO values suffered a large decrease from the second to the third years.

BOD values varied between 0.20 and $13.29 \mathrm{mg} / \mathrm{l}$, with an average of 3-4 mg/l (Fig. 4, Tabs. 3 and 6 ).

In 1969 the dry season was especially long and intense, giving rise to a concentration of organic matter and, in August, to an increase in the oxygen demand. In September the values were still relatively high, probably due also to the water bloom. As the samples were incubated in the dark, the algae could have influenced the results through their respiration or through death and decomposition.

Station 5 not always presented the highest values, the reverse being often the case. The BOD in the reservoir, according to Rocha et al. (1972) is partially due to respiration of the autotrophs. To these may be added zooplankters which exhibit small avoidance to the sampling method.

The average BOD values decreased from the first to the third year at the three stations (Tab. 3).

\section{e. Inorganic $\mathrm{N}$ and $\mathrm{P}$}

Ammonia values oscillated between zero and $1.600 \mathrm{mg} / \mathrm{l}$ (Fig. 5, Tab. 7). The highest values were observed at St. 5, what indicates its prevailing origin from domestic and industrial sewage. It is possible that the peak recorded in November, 1969, had been influenced by decomposition of algae, after the water bloom. Similarly, the decomposition of Eichhornia following treatment with herbicide may have contributed to the high peak at St. 5 in August, 1971. The general averages (Tab. 3) point to a trend towards increasing ammonia concentrations during the three years, mainly at St. 5 .

The range of nitrite values was extended, from traces to $1.800 \mathrm{mg} / 1$ (Fig. 6, Tab. 8). From July to December, 1969, nitrite concentrations varied inversely to those of nitrate (Fig. 7). Nitrite values, relatively low in the first samples, increased in November, 1969. This rise may have been caused, in part at least, by the stabilization of nitrogen compounds originating from algal bloom decomposition.

In general, nitrite values were higher at Sts. 5 and 6 , and increased from the first to third year, with a steeper rise during the second year (Tab. 3).

Nitrate occurred in relatively high concentrations during almost the whole period (Fig. 7, Tab. 9). Probably intense consumption by the phytoplankton during the bloom led to the marked fall in November, 1969, at the three stations. On the same occasion, as referred above, the amounts of ammonia and nitrite rose. Possibly the increment in dissolved 
TABLE 6 - BOD (mg/l), at the three stations, from June 1969 to April 1972.

\begin{tabular}{l} 
Date \\
\hline $25 / 06 / 69$ \\
$24 / 07 / 69$ \\
$20 / 08 / 69$ \\
$25 / 09 / 69$ \\
$06 / 11 / 69$ \\
$09 / 12 / 69$ \\
$07 / 01 / 70$ \\
$28 / 01 / 70$ \\
$12 / 03 / 70$ \\
$02 / 04 / 70$ \\
$29 / 04 / 70$ \\
$26 / 05 / 70$ \\
$30 / 06 / 70$ \\
$06 / 08 / 70$ \\
$03 / 09 / 70$ \\
$13 / 10 / 70$ \\
$09 / 11 / 70$ \\
$08 / 12 / 70$ \\
$18 / 01 / 71$ \\
$01 / 03 / 71$ \\
$29 / 03 / 71$ \\
$29 / 04 / 71$ \\
$06 / 05 / 71$ \\
$08 / 06 / 71$ \\
$13 / 07 / 71$ \\
$17 / 08 / 71$ \\
$15 / 09 / 71$ \\
$19 / 10 / 71$ \\
$16 / 11 / 71$ \\
$04 / 01 / 72$ \\
$03 / 02 / 72$ \\
$07 / 03 / 72$ \\
$05 / 04 / 72$
\end{tabular}

\begin{tabular}{l} 
St.5 \\
\hline 6.80 \\
2.90 \\
13.29 \\
11.44 \\
2.00 \\
2.40 \\
4.70 \\
1.90 \\
1.70 \\
2.50 \\
1.30 \\
2.50 \\
- \\
5.90 \\
4.80 \\
- \\
1.20 \\
4.00 \\
-
\end{tabular}

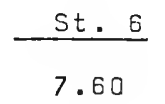

st. 8

2.70

3.10

10.74

7.33

B. 54

7.92

3.10

0.60

2.00

7. 21

3.80

2.70

1.60

1.40

$\cdot 2.30$

180

2.30

630

4.60

570

4.50

3.40

7.10

9.20

3.00

3.90

1.80

1.90

1.90

1.10

1.50

1.60

I. $50^{\circ}$

3.60

4.10

2.80

3.20

4.30

4.00

4.90

4.60

3.10

6.30

4.70

1.70

2.00

2.40

1.30

2.20

3.60

3.20 


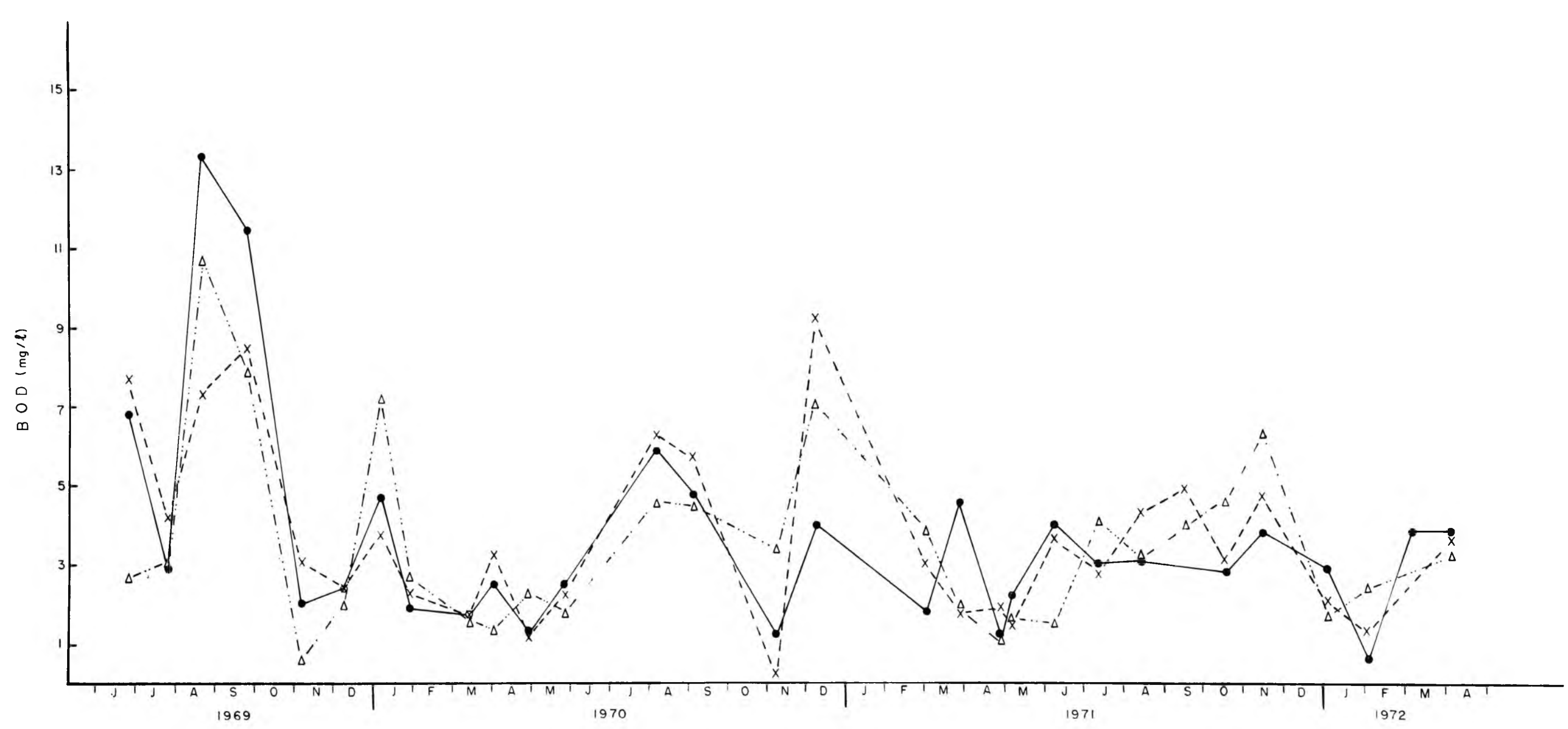

Fig. 4 - Biochemical oxygen demand $(\mathrm{mg} / \mathrm{l})$, at the three stations,

$\begin{array}{llll}- \text { St. } 5 & \mathrm{x}----\mathrm{x} & \text { St. } 6 & \Delta-\cdots-\triangle \text { St. } 8\end{array}$ 

TABLE 7 - Ammonia (mg/l), at the three stations, from June 1969 to April 1972.

\begin{tabular}{|c|c|c|c|}
\hline Date & St. 5 & St. 6 & St. 8 \\
\hline $25 / 06 / 69$ & $0 \quad 047$ & 0.240 & 0.170 \\
\hline $24 / 07 / 69$ & $0 \quad 392$ & $0 \quad 240$ & $0 \quad 157$ \\
\hline $20 / 08 / 69$ & $0 \quad 176$ & 0265 & 0.090 \\
\hline $25 / 09 / 69$ & $0 \quad 178$ & 0.242 & - \\
\hline $06 / 11 / 69$ & 0670 & $0 \quad 319$ & 0.239 \\
\hline $09 / 12 / 69$ & $0 \quad 525$ & $0 \quad 140$ & $0 \quad 152$ \\
\hline $07 / 01 / 70$ & 0286 & $0 \quad 101$ & 0246 \\
\hline $28 / 01 / 70$ & 0180 & $0 \quad 150$ & $0 \quad 145$ \\
\hline $12 / 03 / 70$ & 0.112 & $0 \quad 072$ & $0 \quad 004$ \\
\hline $02 / 04 / 70$ & 0.338 & 0224 & $0 \quad 028$ \\
\hline $29 / 04 / 70$ & $0 \quad 371$ & 0.187 & $0 \quad 128$ \\
\hline $26 / 05 / 70$ & $0 \quad 120$ & $0 \quad 090$ & $0 \quad 060$ \\
\hline $30 / 06 / 70$ & $0 \quad 150$ & - & - \\
\hline $06 / 08 / 70$ & 0120 & $0 \quad 200$ & $0 \quad 060$ \\
\hline $03 / 09 / 70$ & 0260 & $0 \quad 130$ & $0 \quad 010$ \\
\hline $13 / 10 / 70$ & 0.270 & $0 \quad 090$ & $0 \quad 030$ \\
\hline $09 / 11 / 70$ & 0300 & $0 \quad 150$ & 0.010 \\
\hline $08 / 12 / 70$ & 0390 & $0 \quad 120$ & $0 \quad 000$ \\
\hline $18 / 01 / 71$ & 0.300 & 0160 & 0.090 \\
\hline $01 / 03 / 71$ & $0 \quad 620$ & $0 \quad 570$ & 0.300 \\
\hline $29 / 03 / 71$ & 0700 & $0 \quad 620$ & 0230 \\
\hline $29 / 04 / 71$ & 0.690 & 0600 & 0200 \\
\hline $06 / 05 / 71$ & 0160 & 0160 & 0.230 \\
\hline $08 / 06 / 71$ & 0.380 & 0330 & 0300 \\
\hline $13 / 07 / 71$ & - & 0.330 & - \\
\hline $17 / 08 / 71$ & 1.600 & $0 \quad 130$ & 0.600 \\
\hline $15 / 09 / 71$ & $0 \quad 540$ & $0 \quad 040$ & 0.020 \\
\hline $19 / 10 / 71$ & 0260 & 0460 & 0240 \\
\hline $16 / 11 / 71$ & 0.060 & $0 \quad 060$ & $0 \quad 000$ \\
\hline $04 / 01 / 72$ & - & - & - \\
\hline $03 / 02 / 72$ & - & - & - \\
\hline $07 / 03 / 72$ & 0110 & $0 \quad 020$ & 0000 \\
\hline $05 / 04 / 72$ & 0160 & $0 \quad 140$ & $0 \quad 020$ \\
\hline
\end{tabular}


TABLE 8 - Nitrite $(\mathrm{mg} / \mathrm{l})$, at the three stations, from June 1969 to April 1972.

\begin{tabular}{|c|c|c|c|}
\hline Date & St. 5 & St. 6 & St. 8 \\
\hline $25 / 06 / 69$ & 00100 & $0 \quad 0030$ & $0 \quad 0020$ \\
\hline $24 / 07 / 69$ & traces & traces & traces \\
\hline $20 / 08 / 69$ & 00016 & $0 \quad 0020$ & 00012 \\
\hline $25 / 09 / 69$ & 00012 & $0 \quad 0012$ & 0.0040 \\
\hline $06 / 11 / 69$ & 01200 & $0 \quad 1400$ & $0 \quad 1200$ \\
\hline $09 / 12 / 69$ & 00058 & $0 \quad 0026$ & $0 \quad 0076$ \\
\hline $07 / 01 / 70$ & $0 \quad 0054$ & $0 \quad 0052$ & $0 \quad 0040$ \\
\hline $28 / 01 / 70$ & $0 \quad 0020$ & $0 \quad 0017$ & 0.0016 \\
\hline $12 / 03 / 70$ & 0.0030 & 0.0024 & $0 \quad 0012$ \\
\hline $02 / 04 / 70$ & $0 \quad 0052$ & $0 \quad 0056$ & $0 \quad 0030$ \\
\hline $29 / 04 / 70$ & $0 \quad 0034$ & $0 \quad 0040$ & $0 \quad 0016$ \\
\hline $26 / 05 / 70$ & 01000 & 01000 & 01000 \\
\hline $30 / 06 / 70$ & $0 \quad 0800$ & 0.1000 & 02000 \\
\hline $06 / 08 / 70$ & 0.0750 & 01100 & $0 \quad 2350$ \\
\hline $03 / 09 / 70$ & 02000 & $0 \quad 2000$ & $0 \quad 0400$ \\
\hline $13 / 10 / 70$ & 03000 & $0 \quad 1100$ & O DEOO \\
\hline $09 / 11 / 70$ & 02100 & 01000 & $0 \quad 0500$ \\
\hline $08 / 12 / 70$ & - & - & - \\
\hline $18 / 01 / 71$ & 01200 & 00900 & $0 \quad 0400$ \\
\hline $01 / 03 / 71$ & 09000 & 05500 & 1.7000 \\
\hline $29 / 03 / 71$ & 05600 & 08800 & 07200 \\
\hline $29 / 04 / 71$ & $0 \quad 4900$ & 07000 & 07100 \\
\hline $06 / 05 / 71$. & 0.0800 & 01100 & $0 \quad 0700$ \\
\hline $08 / 06 / 71$ & $0 \quad 0200$ & $0 \quad 0200$ & 0.0 .100 \\
\hline $13 / 07 / 71$ & - & 0.3300 & - \\
\hline $17 / 08 / 71$ & $0 \quad 0700$ & 01600 & 01000 \\
\hline $15 / 09 / 71$ & 01000 & 02500 & $0 \quad 0500$ \\
\hline $19 / 10 / 71$. & 02000 & 00200 & 0.0200 \\
\hline $16 / 11 / 71$. & $0 \quad 0800$ & 01000 & 0.0600 \\
\hline $04 / 01 / 72$ & - & - & - \\
\hline $03 / 02 / 72$ & - & - & - \\
\hline $07 / 03 / 72$ & 0.0300 & $0 \quad 0200$ & 00100 \\
\hline $05 / 04 / 72$ & $0 \quad 0400$ & 00600 & $0 \quad 0200$ \\
\hline
\end{tabular}




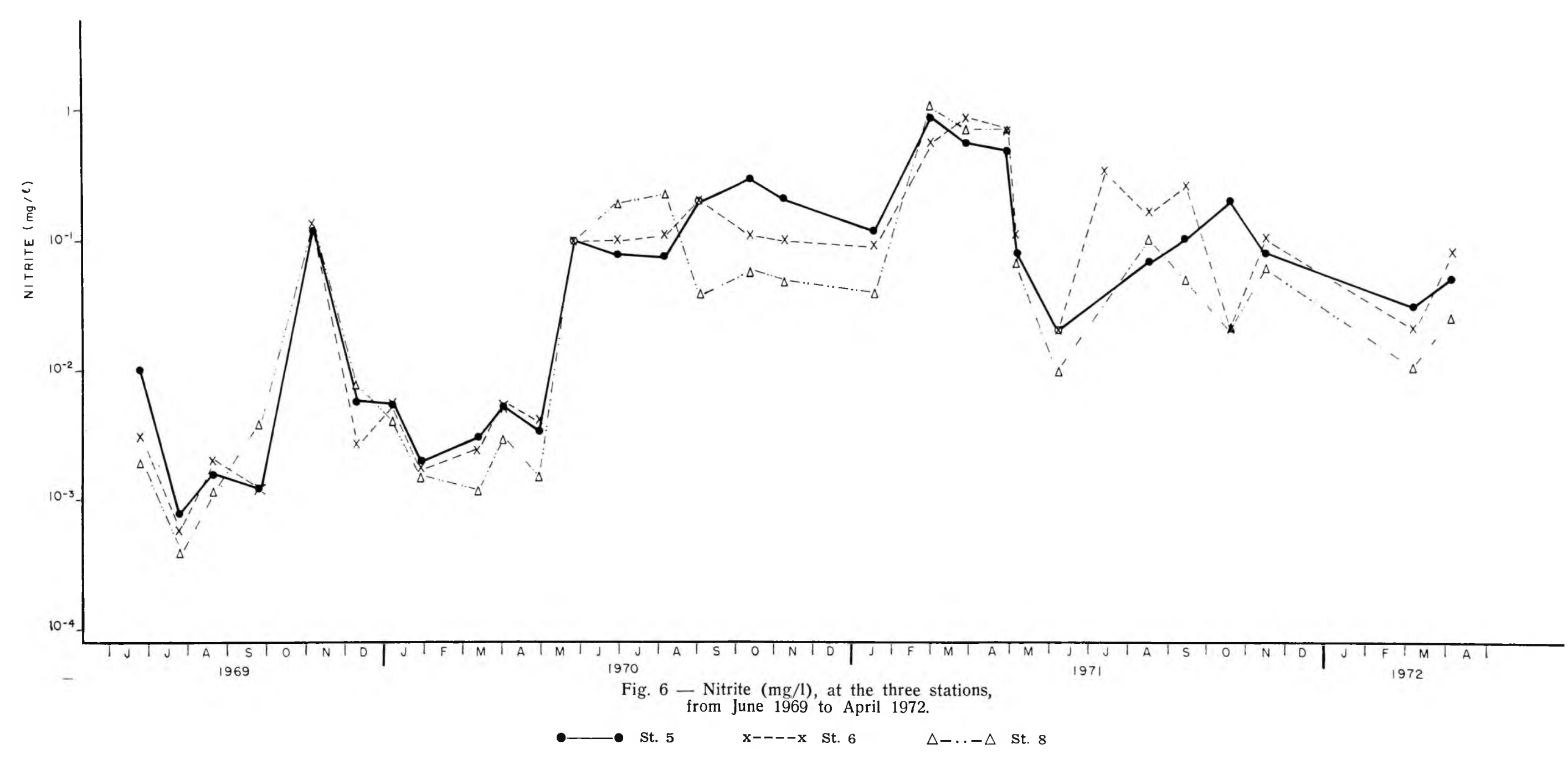



TABLE 9 - Nitrate (mg/l), at the three stations, from June 1969 to April 1972.

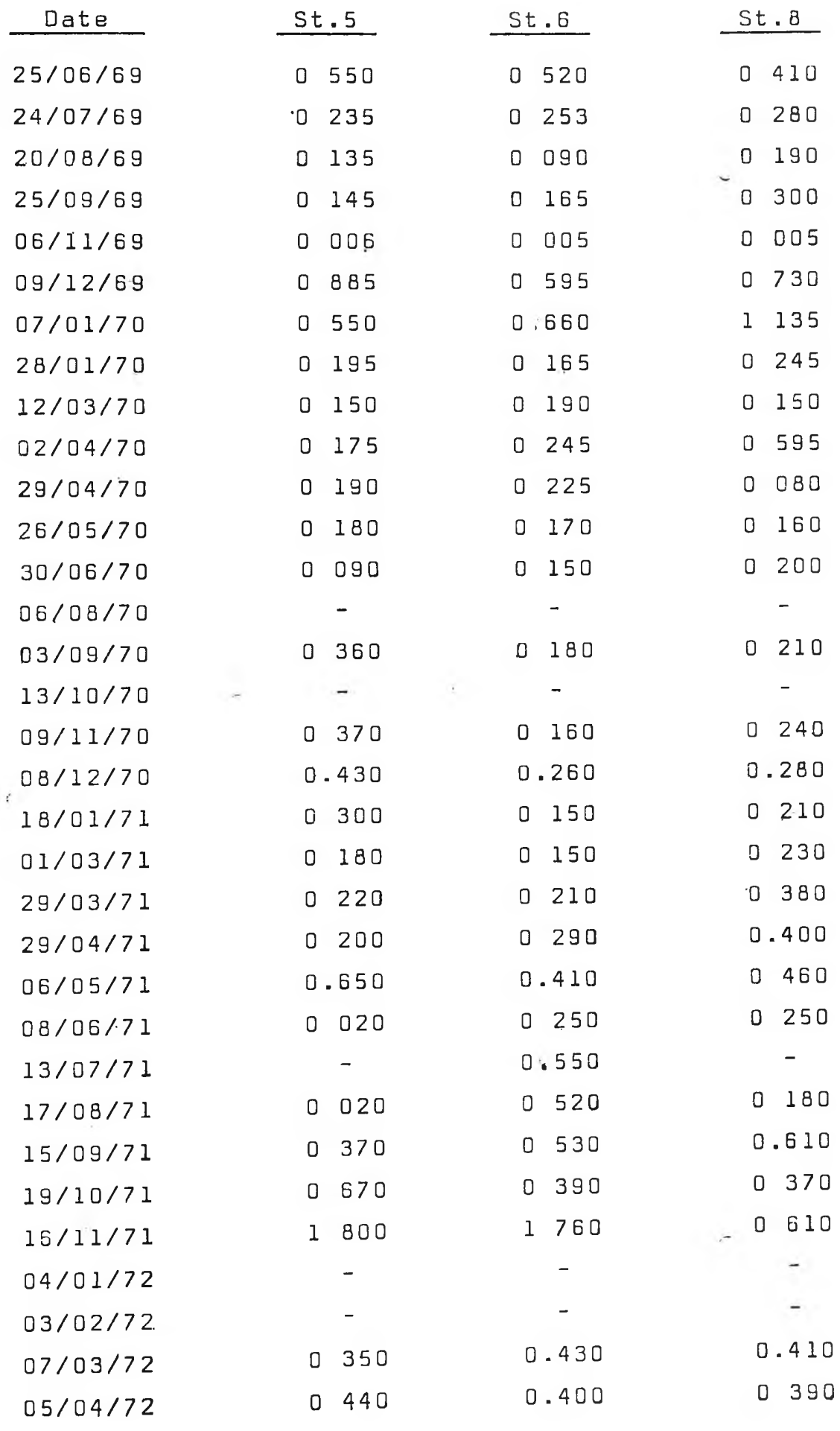




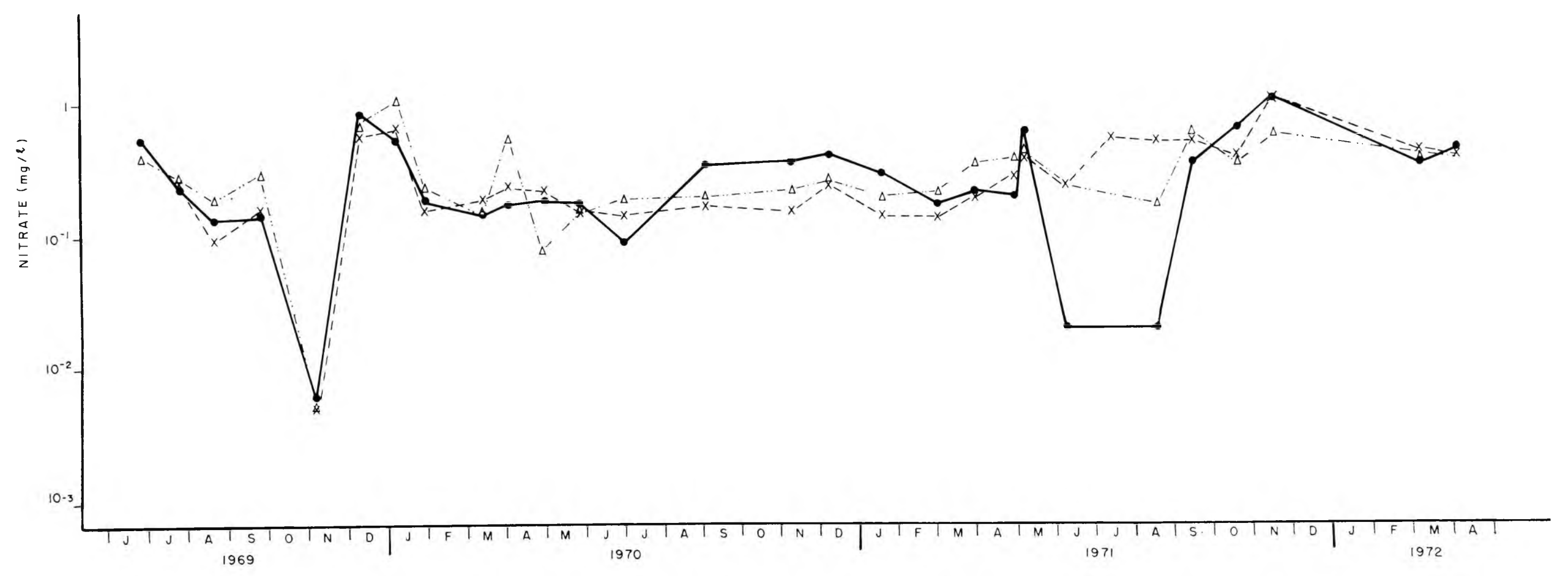

$$
\text { Fig. } 7 \text { - Nitrate }(\mathrm{mg} / \mathrm{l}) \text {, at the three stations, }
$$

$\bullet$ St. $5 \quad \mathbf{x}----\mathbf{x}$ St. $6 \quad \Delta-\cdots-\Delta$ St. 8 
nitrogen may have arisen not only from the decomposition of the algae, but also from nitrogenous wastes excreted by Anabaena spiroides. It is known that several algae, including species of Anabaena (A. variabilis, $A$. gelatinosa, and $A$. cylindrica) excrete nitrogenous substances as amides, aminoacids and polypeptides (Hartman, 1960).

The nitrate peak of December, 1969, coincided with the nitrite fall, pointing clearly to its origin from the oxidation of the latter. In the third year, nitrate averages are high as compared with the two previous years (Tab. 3).

Phosphate concentrations varied from zero to $0.360 \mathrm{mg} / 1$ (Fig. 8, Tab. 10). In July, 1969, phosphate concentrations were higher than in the previous month. Although data from August are lacking, it is possible that levels favourable to the bloom of A. spiroides in September were maintained.

Station 8 was usually the poorest in phosphate concentrations, due probably to previous phytoplankton consumption and sedimentation. Phosphate averages increased from the first to the third years at the three stations. (Tab. 11).

\section{f. Chlorophyll}

Chlorophyll a values in superficial waters varied from 0.001 to $1100 \mathrm{mg} / \mathrm{l}$ during the period from June, 1969, to June, 1971 (Fig. 9, Tab. 12). High values were recorded in September, 1969, during the bloom.

Metabolites liberated by blooming algae can have an antagonistic effect upon other species of algae, upon animals, and even upon themselves at the peak of the bloom (Tassigny and Lefèvre, 1971). Experimental work on Anabaena spiroides has shown that this species can inhibit growth of other algae such as Pediastrum clathratum var. punctulatum, $P$. borianum, Cosmarium lundelli and C. obtusatum (Hartman, 1960).

In November, 1969, the fall in the concentration of chlorophyll a is related to the death of the algae following the bloom, probably there being no time nor favourable amounts of nitrate for a recovery of the phytoplankton populations.

A new peak in the beginning of January, 1970, was followed by a drop at the end of the same month, what could be related to a flood that occurred at the middle of the month. The lowest chlorophyll concentrations were recorded in September-October, 1970, when transparencies were reduced (Fig. 2). Chlorophyll values, as well as transparency ones, increased in November, at least at Sts. 6 and 8.

In general, phytoplankton was more abundant at St. 8, followed by Sts. 6 and 5. In the first two years, during which chlorophyll values were measured, a decrease from the first to the second was observed (Tab. 11). 


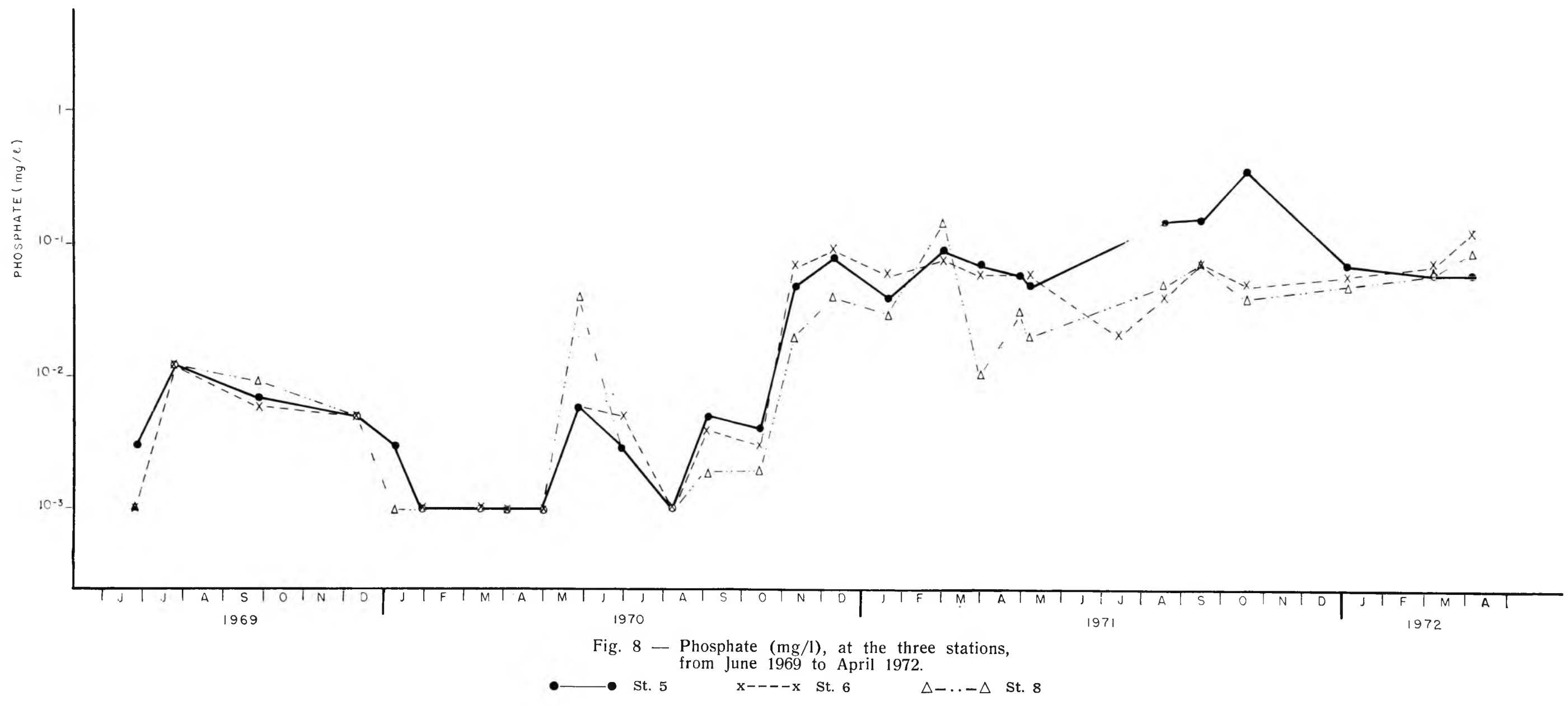



TABLE 10 - Phosphate $(\mathrm{mg} / \mathrm{l})$, at the three stations, from June 1969 to April 1972.

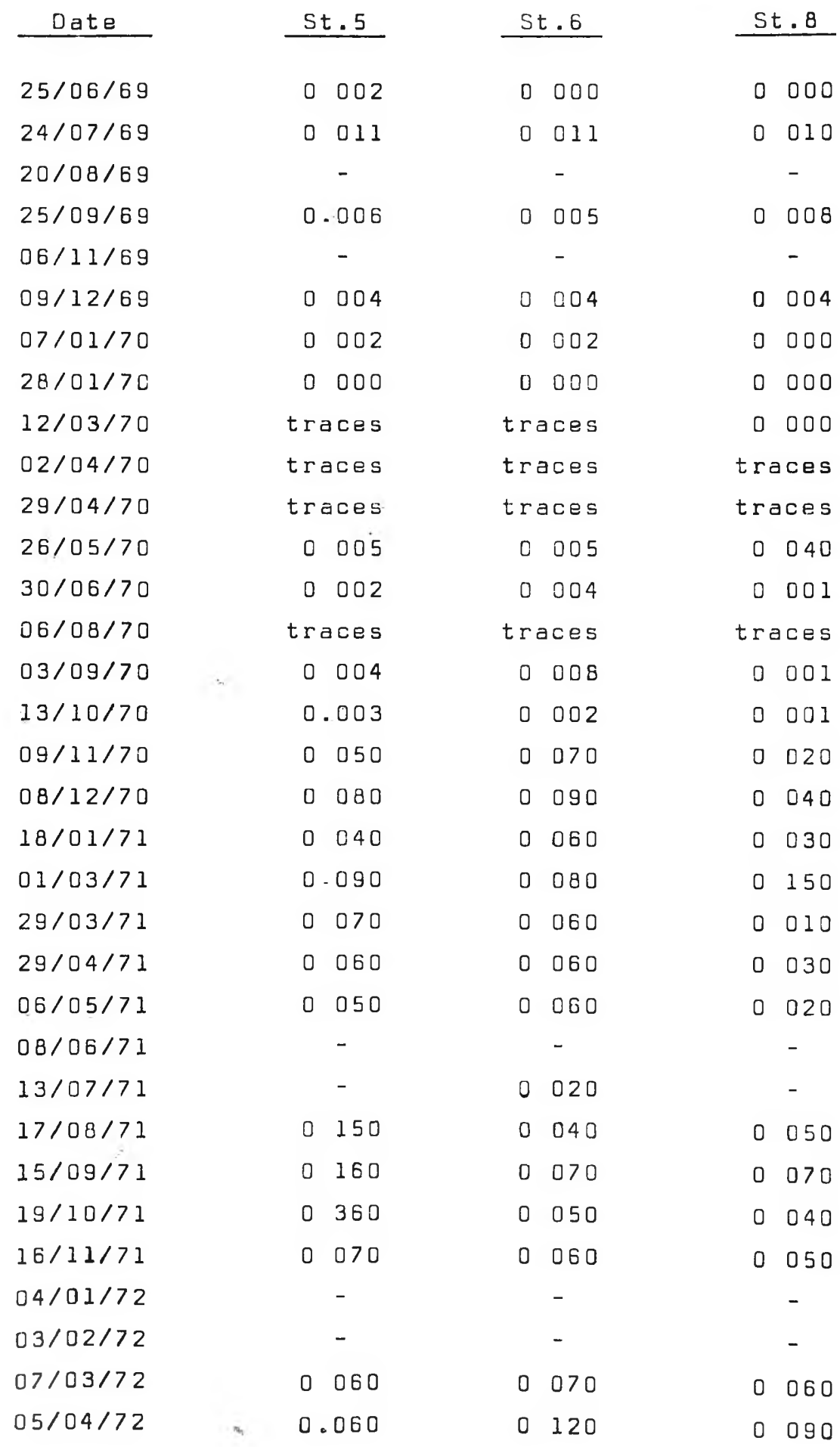


TABLE 11 - Average values of phosphate, chlorophyll, coliform bacteria and Cladocera densities, at each stations, in the three years.

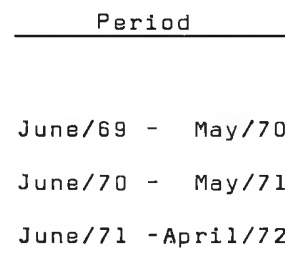

June/69 - May/70

June/70 June/71

$\begin{array}{lr}\text { June/69 } & \text { May/70 } \\ \text { June/70 } & \text { May/71 } \\ \text { June/71 } & - \text { April/72 }\end{array}$

June/71-April/72

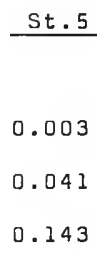

.143

0.1116

Chlorophyli (mg/l)

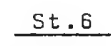

Phosphate (mg/1)

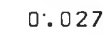

0.044

0.061

0.0830

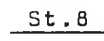

0.006

0.028

0.060

0.1485

0.0360

0.0685

0.1144

0.0398

$$
\text { Coliform (MPN coli/l00 } \mathrm{ml} \text { ) }
$$

$\begin{array}{cccc}79 \times 10^{3} & 17 \times 10^{2} & 466 & 27 \times 10^{3} \\ 15 \times 10^{3} & 356 & 25 \times 10^{2} & 59 \times 10^{2} \\ 59 \times 10^{3} & 53 \times 10^{2} & 22 \times 10^{2} & 22 \times 10^{3}\end{array}$

$$
\text { Cladocera }\left(\mathrm{N}^{e} \mathrm{i} / \mathrm{m}^{3}\right)
$$

$\begin{array}{rrrrrr}\text { June/69 } & \text { May/70 } & 18937 & 12019 & 13969 & 14975 \\ \text { June/70 } & \text { May/71 } & 24606 & 26189 & 20278 & 23691 \\ \text { June/71 } & - \text { April/72 } & 1918 & 6263 & 7695 & 5292\end{array}$




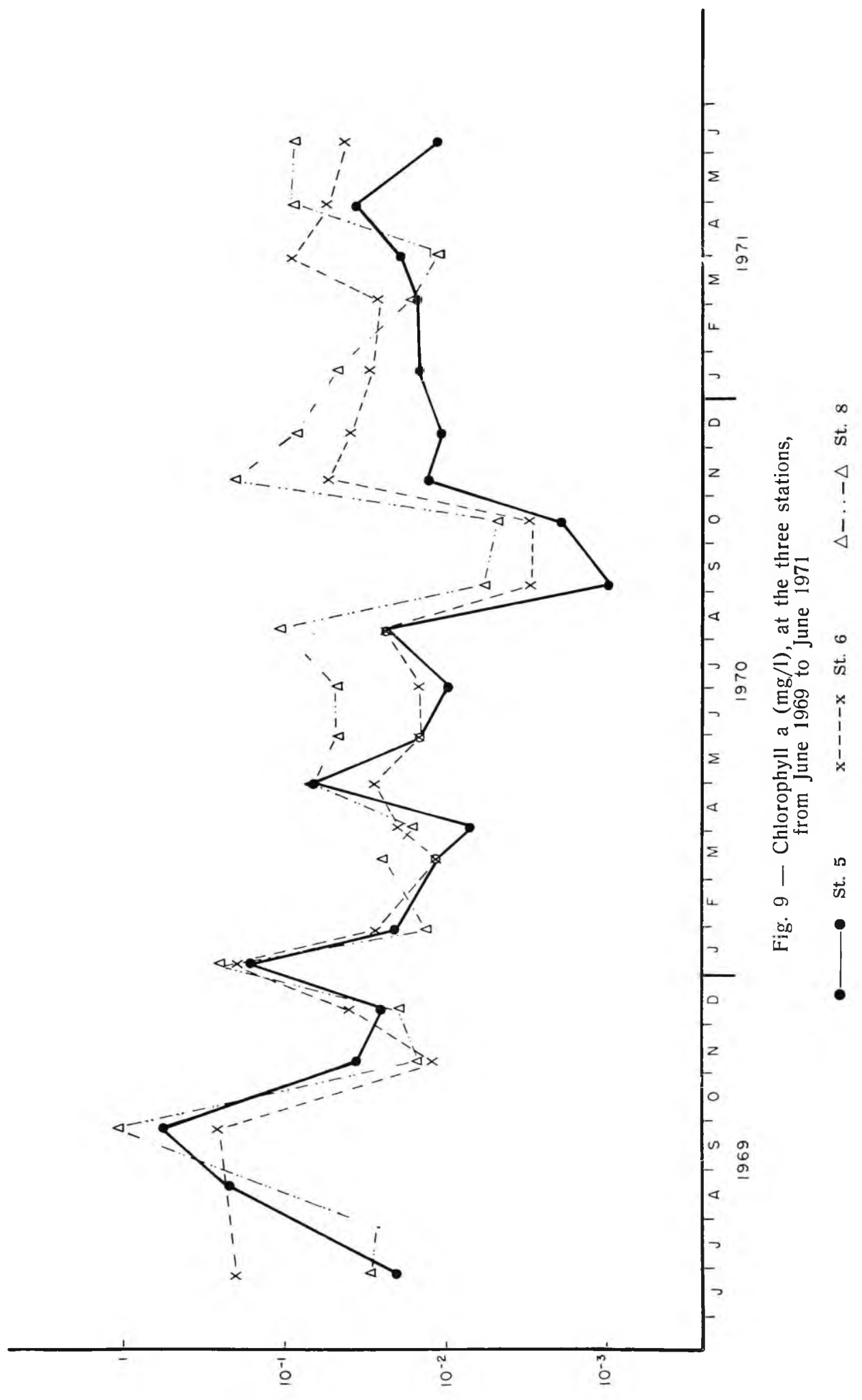

$(x / 6$ ) 
TABLE 12 - Chlorophyll (mg/l), at the three stations, from June 1969 to June 1971.

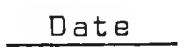

$25 / 06 / 69$

$24 / 07 / 69$

$20 / 08 / 69$

$25 / 09 / 69$

$06 / 11 / 69$

$09 / 12 / 69$

$07 / 01 / 70$

$28 / 01 / 70$

$12 / 03 / 70$

$02 / 04 / 70$

$29 / 04 / 70$

$26 / 05 / 70$

$30 / 06 / 70$

$06 / 08 / 70$

$03 / 09 / 70$

$13 / 10 / 70$

$09 / 11 / 70$

$08 / 12 / 70$

$18 / 01 / 71$

$01 / 03 / 71$

$29 / 03 / 71$

$29 / 04 / 71$

$06 / 05 / 71$

$08 / 06 / 71$

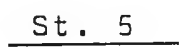

00200

0.2700

$0 \quad 5840$

$0 \quad 0360$

0.0250

01680

$0 \quad 0210$

$0 \quad 0115$

0.0073

$0 \quad 0700$

0.0150

$0 \quad 0100$

$0 \quad 0250$

0.0010

$0 \quad 0020$

$0 \quad 0140$

00110

$0 \quad 0150$

00160

$0 \quad 0200$

$0 \quad 0390$

$0 \quad 0115$
St. 6

02000

$0 \quad 0300$

$0 \quad 0280$

11000

0.0150

$0 \quad 0210$

02640

$0 \quad 0140$

0.0252

$0 \quad 0168$

$0 \quad 0280 \quad 0 \quad 0700$

$0.0150 \quad 0.0500$

$00150 \quad 0 \quad 0500$

$0.0250 \quad 01100$

$00030 \quad 0.0060$

$00030 \quad 0 \quad 0050$

$0 \quad 0560$

- 2200

0.0400

$0 \quad 0900$

$0 \quad 0300$

0.0500

$0 \quad 0270$

$0 \quad 0170$

$0 \quad 0970$

$0 \quad 0120$

$0 \quad 0560$

$0 \quad 0970$ 


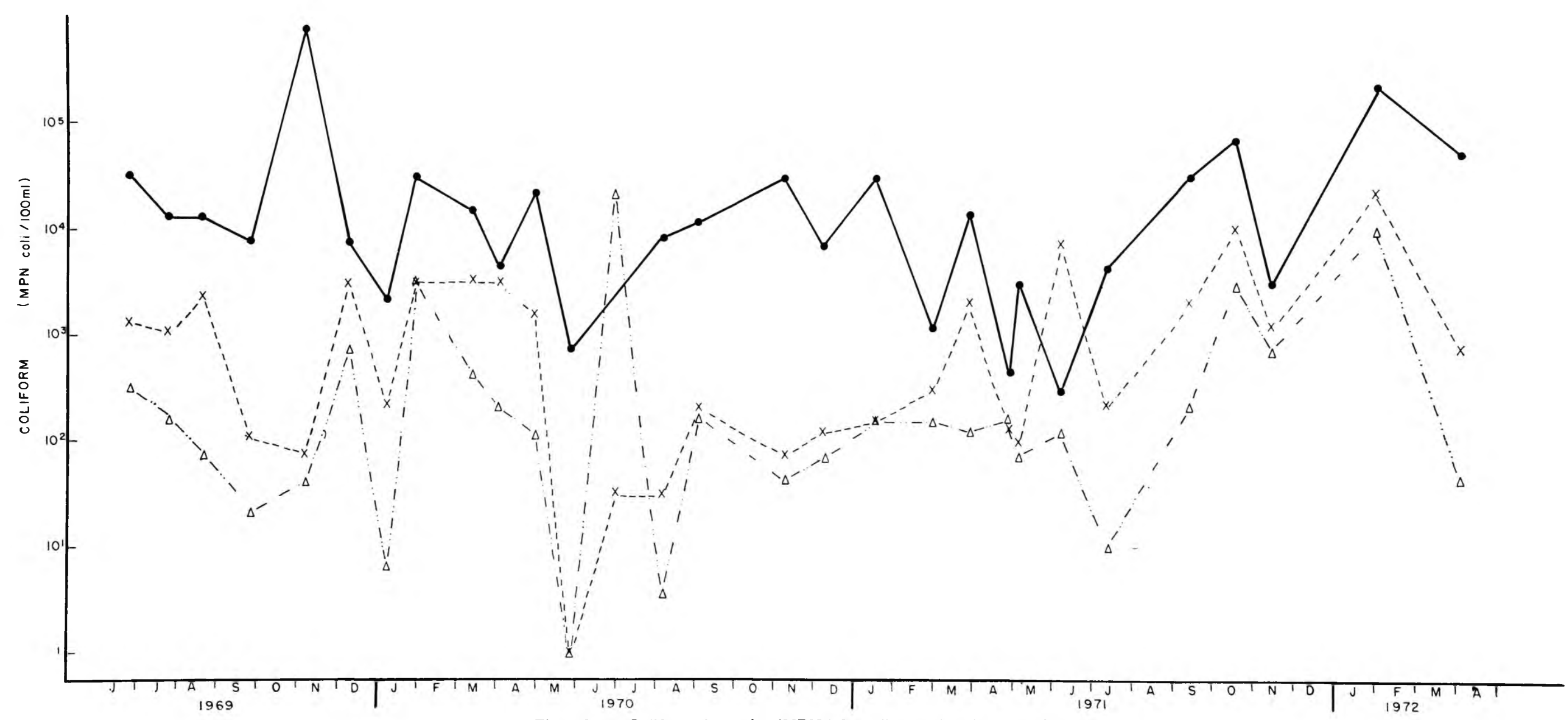

Fig. 10 - Coliform bacteria (MPN/100 ml), at the three stations, from June 1969 to April 1972.
$\mathrm{x}----\mathrm{x}$ St. $6 \quad \Delta-\cdots-\triangle$ St. 8 



\section{g Coliform bacteria}

All bacteria of the coliform group are considered here, including faecal, not exclusively faecal, and non-faecal. Most of them, however, live in the gut, being eliminated in the faeces in numbers of 5 to $40 \times 10^{10}$ per person per day (Branco, 1971). Thus, they constitute o good indicator of pollution of a body of water by domestic sewage.

Bacteria numbers were larger at St. 5 , the nearest to the mouth of the river, decreasing at Sts. 6 and 8 (Fig. 10, Tab. 13). Judging by the averages, no increase in coliform bacteria took place during the three years of study except at St. 8 (Tab. 11).

\section{The planktonic Cladocera}

The following limnetic species occurred during the period of study:

Daphnia gessneri Herbst, 1967

Ceriodaphnia cornuta Sars, 1885

Ceriodaphnia reticulata Jurine, 1820

Moina cf. dubia, Herbst in litt.

Moina sp.

Diaphanosoma sp.

Diaphanosoma neotropicum Brehm and Thomsen, 1936

Bosminopsis deitersi Richard, 1895

Bosmina longirostris O.F Müller, 1785

Eubosmina or Neobosmina sp. mina spp.

In countings, the two last species were considered together as Bos-

From the species Ceriodaphnia cornuta, the forms cornuta, rigaudi, and the intermediate between them occurred, as it was observed by Robinson and Robinson (1971) in Lake Chad. In the present work the forms were counted together, although a dominance of cornuta was observed. The eye of rigaudi was larger than that of cornuta, agreeing with Zaret (1969).

Temporal distribution of the populations at Stations 5,6 and 8 .

As it is observed in Figs. 11, 12 and 13 and Tabs. 14, 15 and 16, the more abundant and frequent species were: D. gessneri, Diaphanosoma sp., Bosmina spp. and Ceriodaphnia cornuta. During the first year, $D$. gessneri was numerically dominant. In the following two years the situation altered, in the third year Diaphanosoma sp. being more abundant.

What is noticeable too is that after an increase in the second year, there was a decrease of the populations in the third year, some species 
TABLE 13 - Coliform bacteria (MPN/100 ml), at the three stations, from June 1969 to April 1972.

\begin{tabular}{l} 
Date \\
\hline $25 / 06 / 69$ \\
$24 / 07 / 69$ \\
$20 / 08 / 69$ \\
$25 / 09 / 69$ \\
$06 / 11 / 69$ \\
$09 / 12 / 69$ \\
$07 / 01 / 70$ \\
$28 / 01 / 70$ \\
$12 / 03 / 70$ \\
$02 / 04 / 70$ \\
$29 / 04 / 70$ \\
$26 / 05 / 70$ \\
$30 / 06 / 70$ \\
$06 / 08 / 70$ \\
$03 / 09 / 70$ \\
$13 / 10 / 70$ \\
$09 / 11 / 70$ \\
$08 / 12 / 70$ \\
$18 / 01 / 71$ \\
$01 / 03 / 71$ \\
$29 / 03 / 71$ \\
$29 / 04 / 71$ \\
$06 / 05 / 71$ \\
$08 / 06 / 71$ \\
$13 / 07 / 71$ \\
$17 / 08 / 71$ \\
$15 / 09 / 71$ \\
$19 / 10 / 71$ \\
$16 / 11 / 71$ \\
$04 / 01 / 72$ \\
$03 / 02 / 72$ \\
$07 / 03 / 72$ \\
$05 / 04 / 72$
\end{tabular}

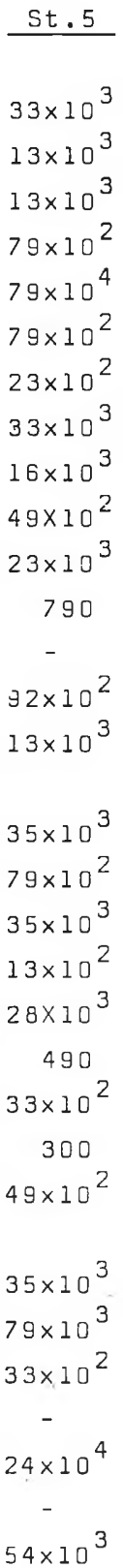

St. 6

$13 \times 10^{2}$

$11 \times 10^{2}$

$24 \times 10^{2}$

110

79

$33 \times 10^{2}$

230

$33 \times 10^{2}$

$35 \times 10^{2}$

$33 \times 10^{2}$

$17 \times 10^{2}$

0

33

33

230

St.8

330

170

79

23

46

790

8

$33 \times 10^{2}$

490

230

130

0

$24 \times 10^{3}$

4

190

79

49

130

79

172

172

330

172

140

172

141

79

130

11

230

230

$22 \times 10^{2}$

$33 \times 10^{2}$

$11 \times 10^{2}$

$13 \times 10^{2}$

790

$24 \times 10^{3}$

$11 \times 10^{3}$

790

49 


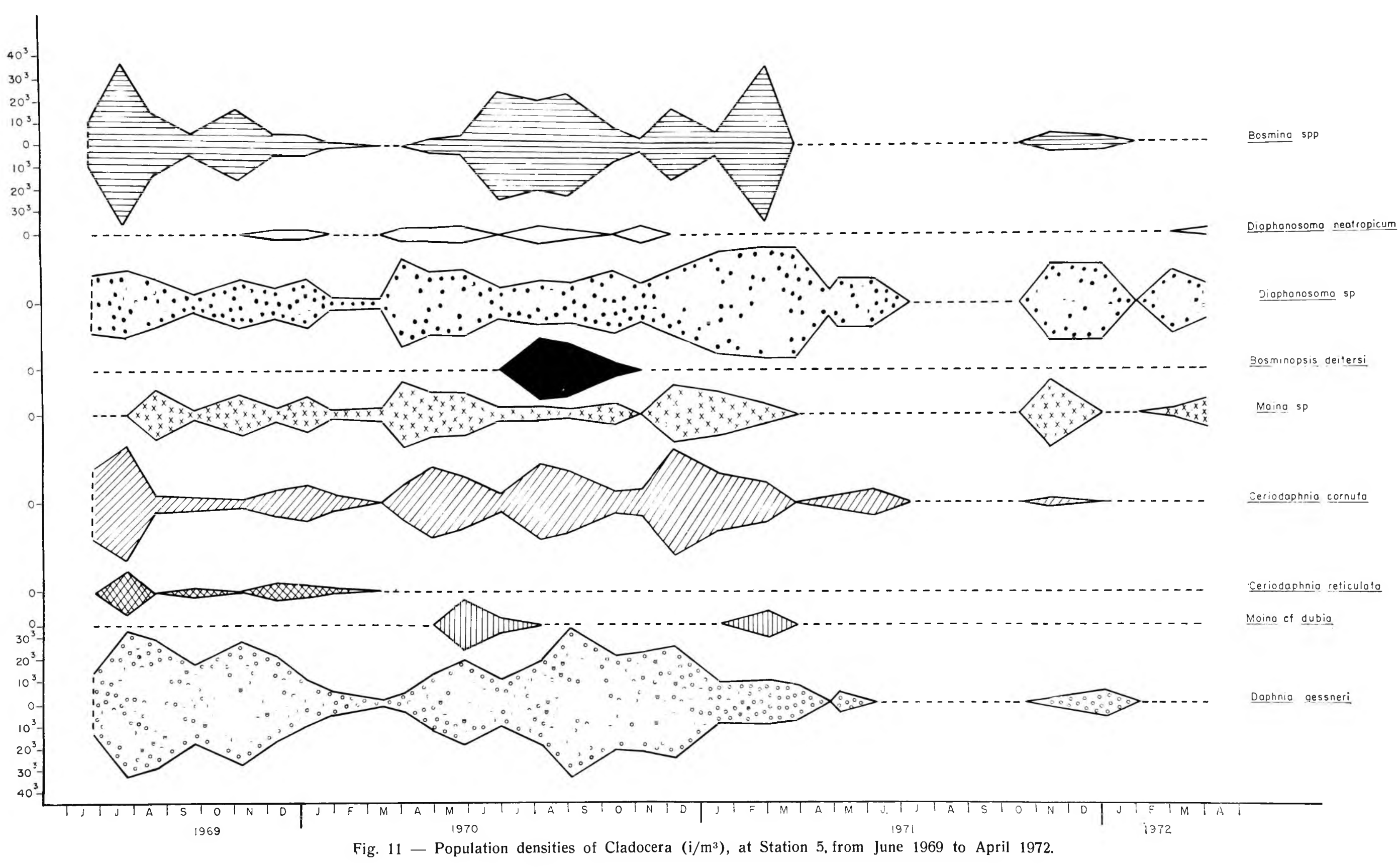






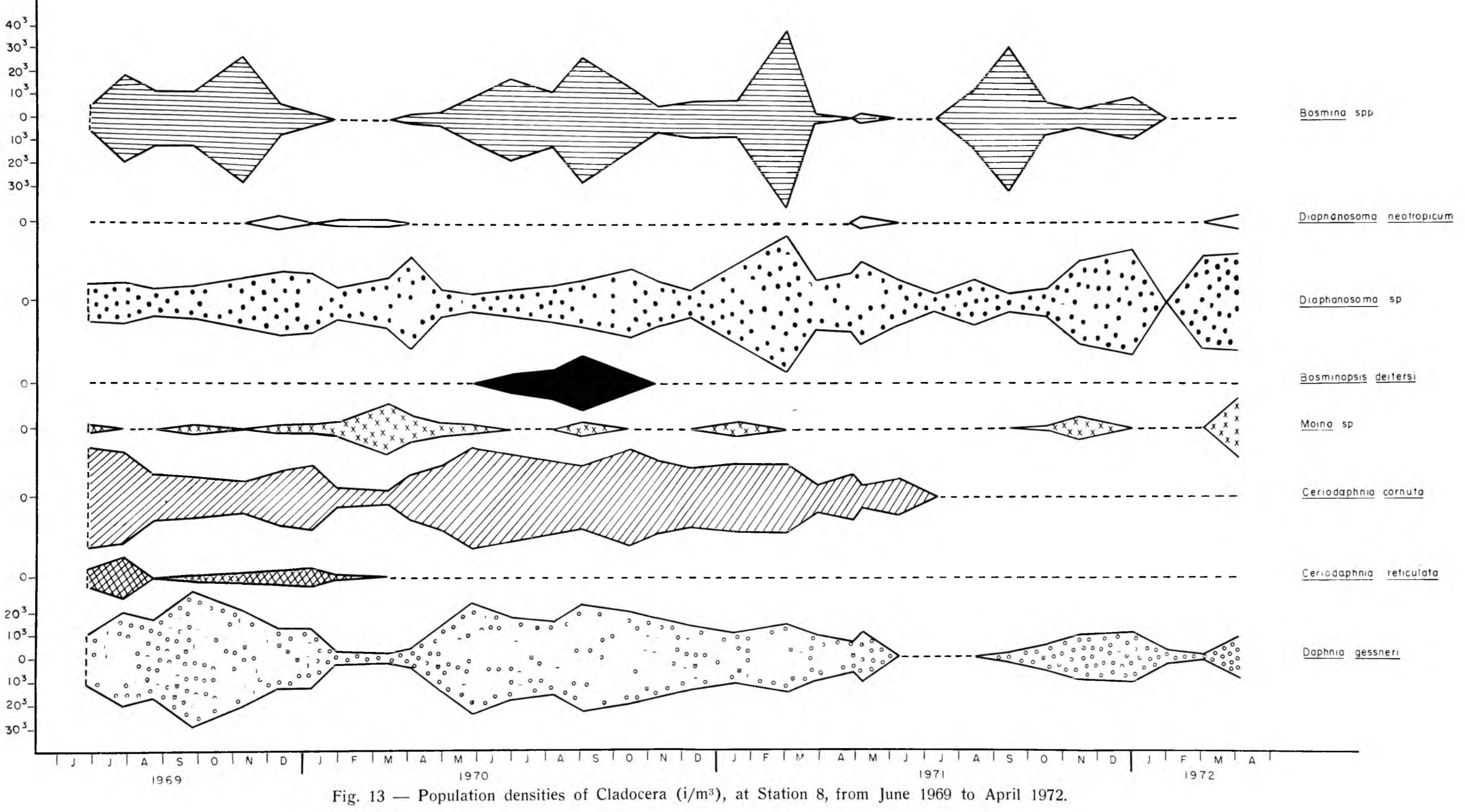





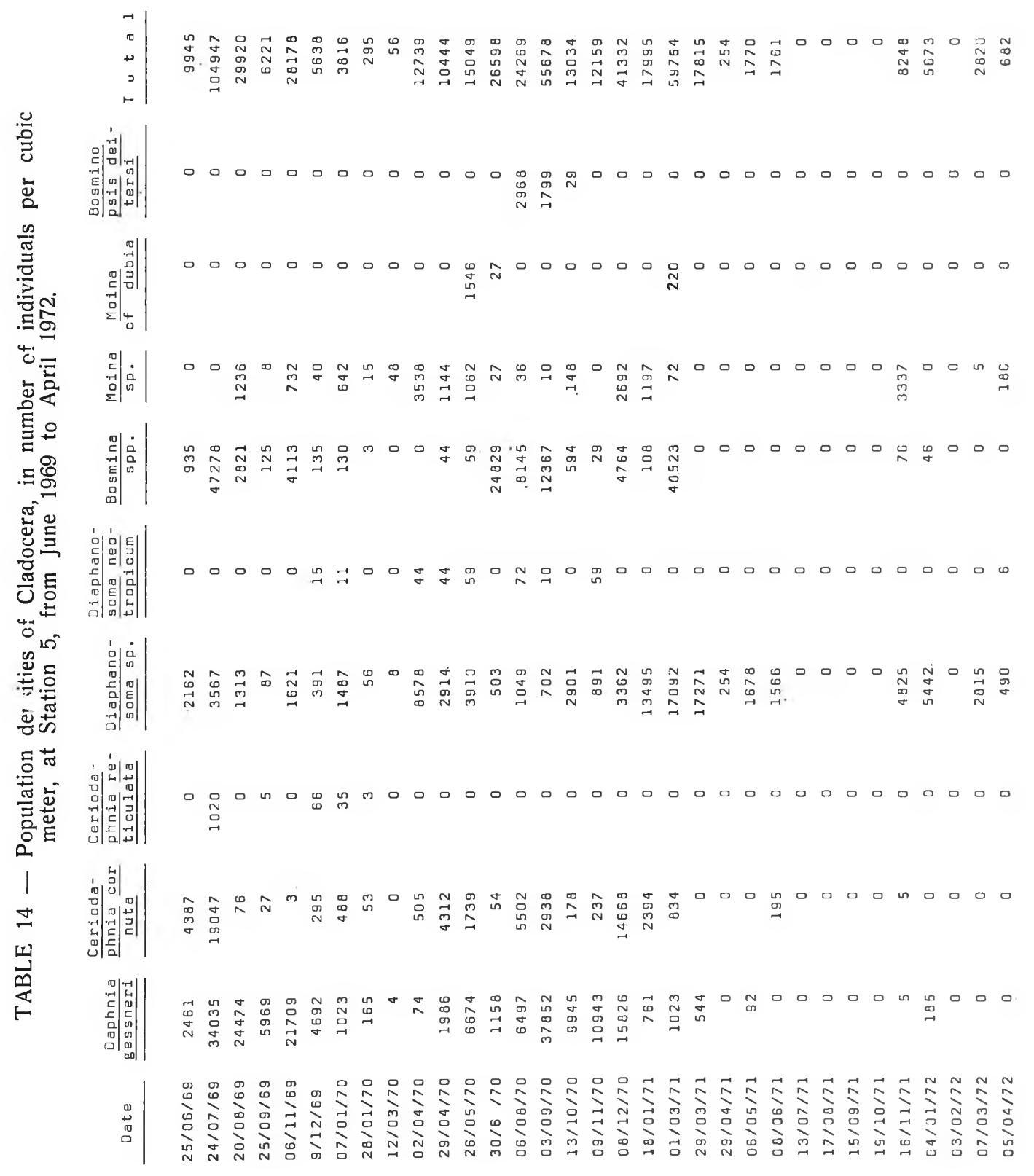




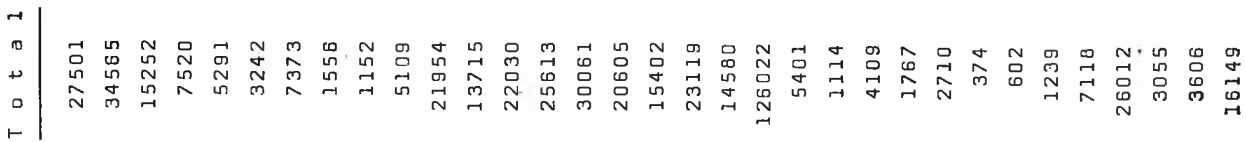

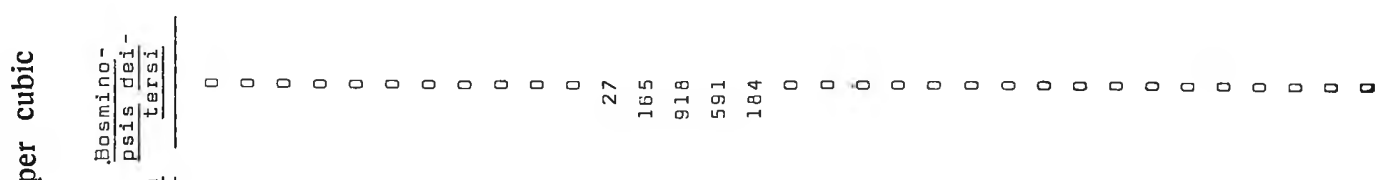

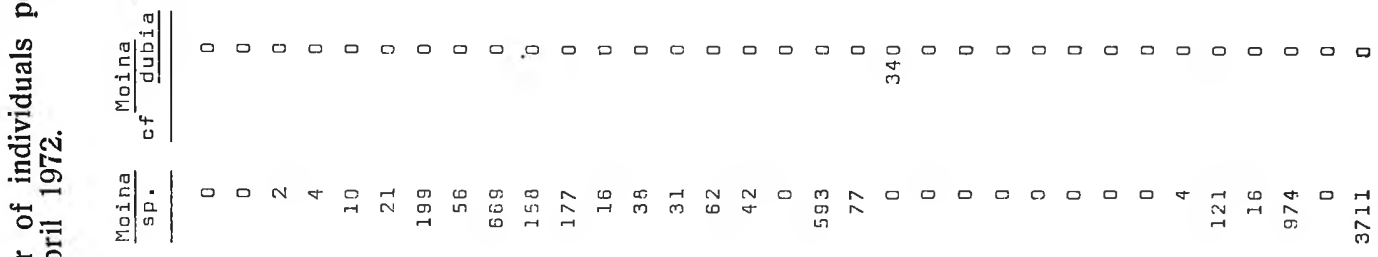
窝是 툐

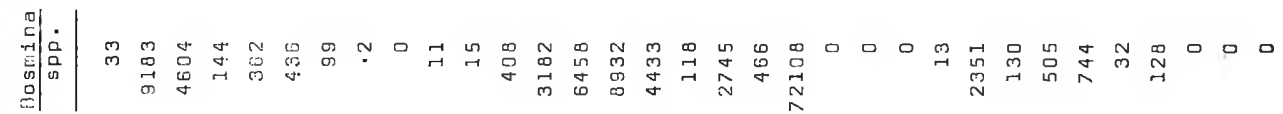
焉葛 等

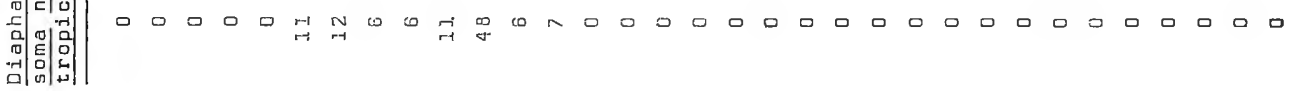
(4)

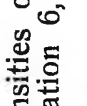

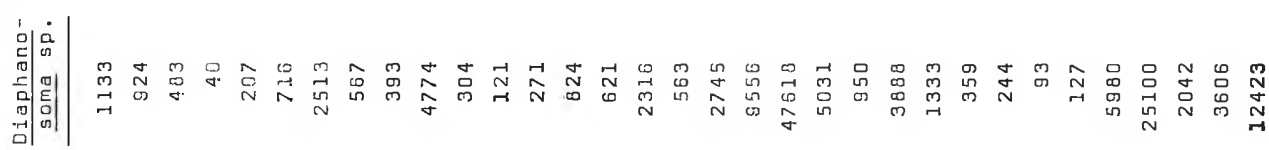

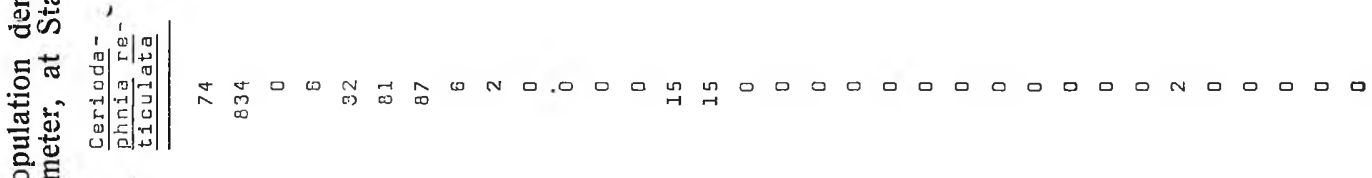
a

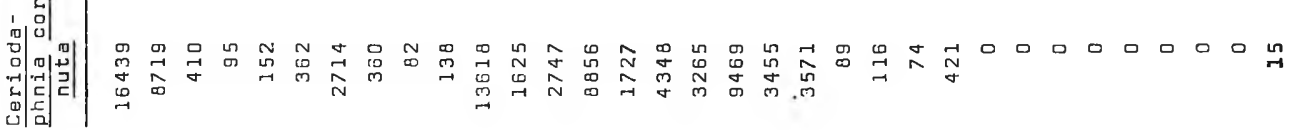

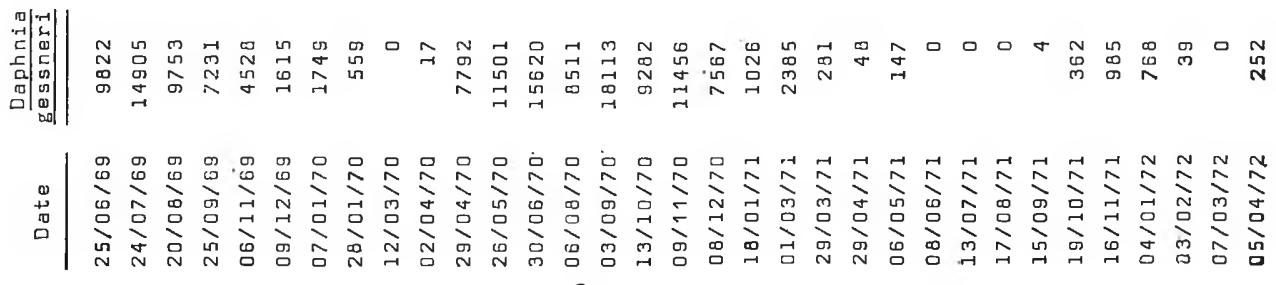




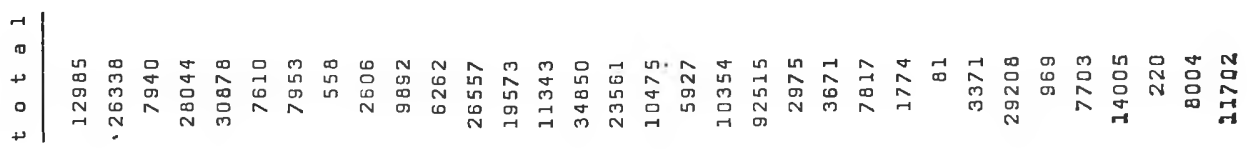

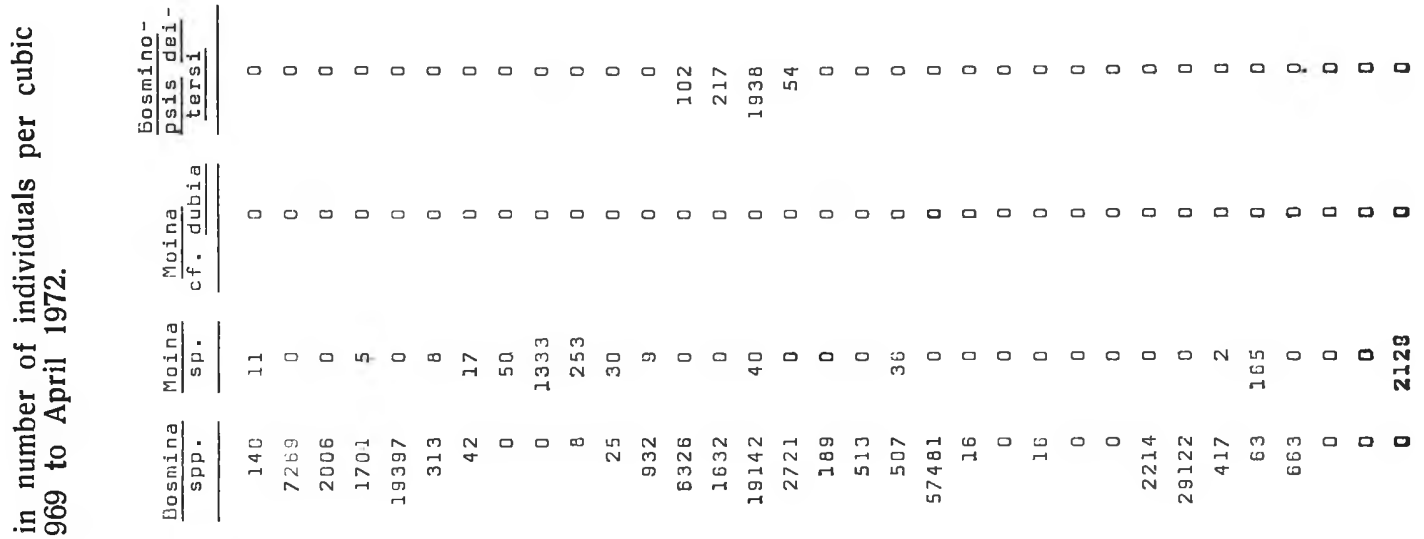

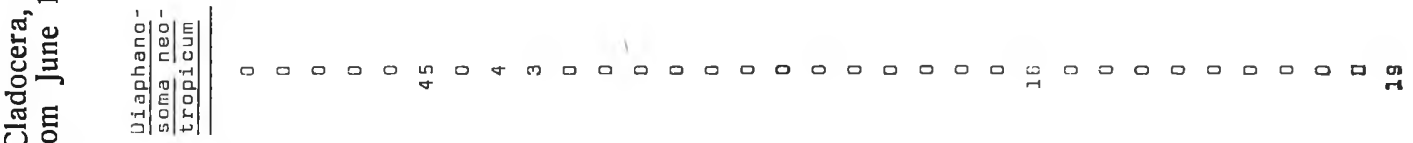

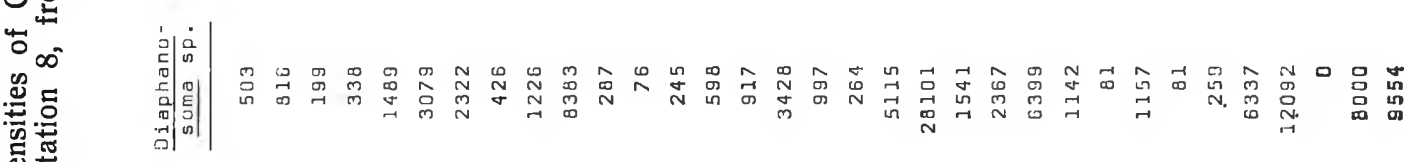
岇芯

禋

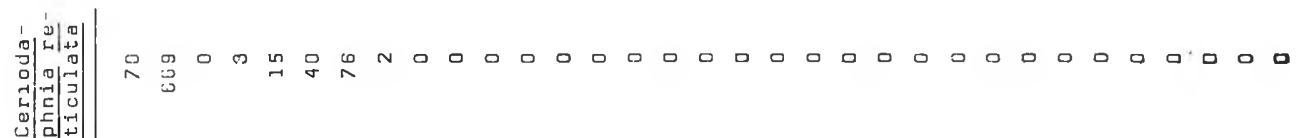

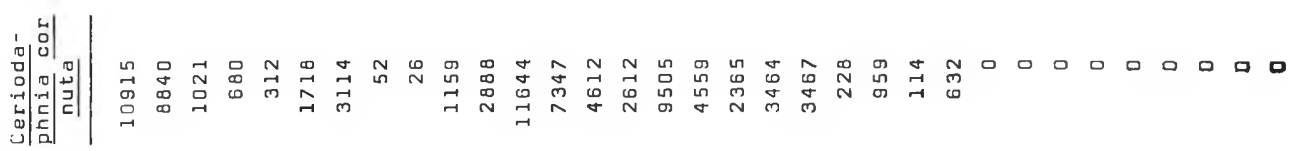

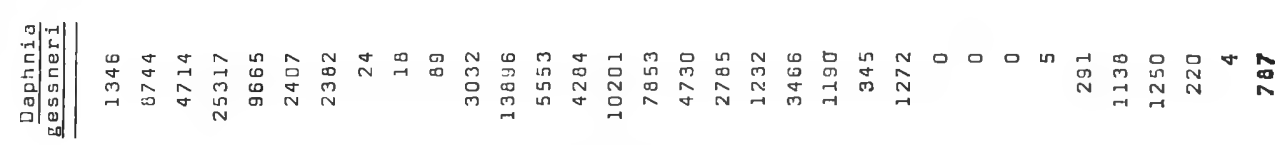

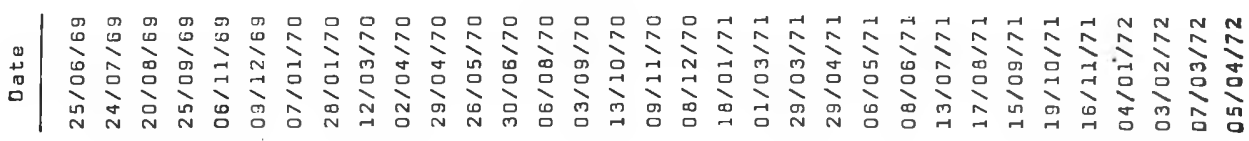


having disappeared from the samples. At St. 5 the general depression was more evident than in the others.

During the water bloom it occurred, with few exceptions, a decrease of the population densities. Another general depression occurred late in January, 1970, extending until March.

Ephippial females and males of $D$. gessneri occurred in several occasions, sometimes in high numbers (Tab. 17). During the water bloom, the number of ephippial females was relatively high at the three stations. In general males appeared in relatively larger numbers, when population densities were high.

TABLE 17 - Occurrence of ephippial females and males of Daphnia gessneri, in number of individuals per cubic meter, at the three stations.

\begin{tabular}{|c|c|c|c|c|c|c|}
\hline & st. & & & & & \\
\hline & ephippial & $0^{7}$ & ephippial q & $\overline{0}$ & ephippial & $\sigma^{*}$ \\
\hline $25 / 06 / 69$ & 0 & 27 & 2 & 36 & 0 & 0 \\
\hline $24 / 07 / 69$ & 20 & 3 & 5 & 29 & 0 & 2 \\
\hline $20 / 08 / 69$ & 300 & 733 & 77 & 0 & 40 & 0 \\
\hline $25 / 09 / 69$ & 158 & 2 & 208 & 0 & 94 & 3 \\
\hline $06 / 11 / 69$ & 11 & 0 & 10 & 10 & 5 & 0 \\
\hline $29 / 04 / 70$ & 29 & 29 & 112 & 145 & 25 & 90 \\
\hline $26 / 05 / 70$ & 0 & 59 & 6 & 102 & 28 & 48 \\
\hline $30 / 06 / 70$ & 3 & 40 & 3 & 249 & 2 & 41 \\
\hline $06 / 08 / 70$ & 0 & 60 & 0 & 217 & 13 & 68 \\
\hline $03 / 09 / 70$ & 12 & $36 !$ & 46 & 435 & 40 & 265 \\
\hline $13 / 10 / 70$ & 11 & 3 & 5 & 127 & 0 & 72 \\
\hline $08 / 12 / 70$ & 3 & 0 & 29 & 29 & 0 & 0 \\
\hline $01 / 03 / 71$ & 5 & 0 & 5 & 0 & 0 & 0 \\
\hline $04 / 01 / 72$ & 0 & 0 & 0 & 16 & 0 & 0 \\
\hline
\end{tabular}

\section{Discussion}

Analysis of the conditions of the system comprising Americana Reservoir, Atibaia River and neighbouring tributaries upstream, shows that the larger alterations in the environment occur after the afflux of Anhumas Stream waters and the wastes of the Rhodia Industry plant into the Atibaia River (Rocha et al., 1972). Although other polluting sources are not neglibigle, they are, however, small as compared with the former. High concentrations of ammonia (13 $\mathrm{mg} / \mathrm{l})$, phosphate $(770 \mathrm{mg} / \mathrm{l})$, coliform bacteria $\left(23 \times 10^{7} \mathrm{MPN}\right.$ coli $\left./ 100 \mathrm{ml}\right)$ and chlorides $(44 \mathrm{mg} / \mathrm{l})$ are found in Anhumas Stream. After the discharge of its waters, and of Rhodia effluents, the waters of Atibaia River suffer a considerable rise in the BOD and in coliform numbers, and a decrease in DO. 
Purification along the river and the reservoir is effective, noticeable by changes in several environmental parameters. In one day, time spent by Atibaia River to run from the mouth of Anhumas Stream to the reservoir, the numbers of coliform bacteria and BOD values decrease. A great deal of organic matter is sedimented at the upper end of the reservoir (Rocha, 1972), the coefficients of organic matter decomposition and sedimentation decreasing along its longitudinal axis (Rocha et al., 1972). By the results presented here, self-purification in the reservoir may be noticed by the decrease in coliform bacteria and ammonia values, and by the increase in transparencies, from St. 5 to 8; the phytoplankton, in $\mathrm{mg} / \mathrm{l}$ of chlorophyll a, is practically non-existent at St. 4 (Rocha et al., 1971), suffers a quick increment at St. 5, continuing to increase toward St. 8; along with the chlorophyll increase, rise the superficial DO concentrations. According to Rocha et al. (1972), the fact that the BOD does not decrease from the upper toward the lower end of the reservoir indicates the influence of phytoplankton respiration, which would introduce a false BOD (Branco, 1971). The benthic fauna and sediments change from types characteristic of polluted waters at St. 4 to types of moderately polluted waters at St. 7 (Rocha, 1972. Stations 1 and 2 of this author correspond to Stations 4 and 7 of the present work, see map, p. 107).

The analysis of the eutrophication process during three years, although not a very extensive period, has revealed several modifications in the ecosystem. During this time there was an increase in inorganic $\mathrm{N}$ and $\mathrm{P}$ concentrations, while the numbers of coliform bacteria did not increase. The increase in nutrients, considering the allochthonous sources, may have been caused mainly by rising industrial sewage discharges and by more and more generalized use of phosphate-containing detergents. Hasler and Swenson (1967) mention the importance of domestic and industrial sewage as nutrient sources, emphasizing that of the phosphate from detergents. The use of these detergents is changing the P: $\mathrm{N}$ ratio in sanitary sewages, that found nowadays in the United States being of 1: 5 (Fruh, in Kawai et al., 1972). The comparison between the high phosphate values of the Anhumas Stream and those of the reservoir, suggests that most of it had been removed from the biogenic cycle by precipitation as insoluble phosphates.

The superficial DO in the reservoir originates primarily from photosynthesis, rather than from atmosferic reaeration (Rocha et al., 1972) and the BOD, as already referred, undergoes much influence from autotrophs. If this is the case, and in the absence of chlorophyll data, it is possible that the small change in the average values of these two factors in the third year, points out that phytoplankton increase did not occur. In general, environment enrichment in nutrients is followed by an increment of the phytoplankton standing crop. This has occurred in Lake Erie (Davis, 1964), and in Lake Washington (Edmondson et al., 1956), before sewage diversion (Edmondson, 1970). In Billings Reservoir, a eutrophic water body whose larger source is São Paulo city sewage, water blooms are common (Branco, 1966; Kawai and Branco, 1969). It should be taken into consideration that the period of study may have been not long enough to ascertain variations in phytoplankton standing crop, although 
as Marshall and Falconer (1973) mention, the high temperatures of tropical regions are favourable to the appearance of eutrophication effects in shorter time than in temperate regions. With exception of phosphate in the first year, inorganic $\mathrm{N}$ and $\mathrm{P}$ concentrations in Americana Reservoir exceeded the limits mentioned by Sawyer (1966), that Stewart and Rohlich (1967) consider as facilitating the occurrence of water blooms. There is a series of factors that can affect phytoplankton development, nutrients being found in favourable amounts in the reservoir.

With regard to $\mathrm{CO}_{2}$ reserve, it is considered high by Rocha et al. (1972), but even in low concentrations, its value as a limiting factor is questionable (Schindler, 1971).

Light, one of the most important factors, can have its penetration into the water much restricted by turbidity or colour. Thus, researches carried on Lake Erie (Verduim, 1954) and Cachoeira da Graça Reservoir (Branco, 1961) revealed turbidity and colour, respectively, to be the limiting factors to phytoplankton development. The importance of light penetration in Americana Reservoir can be noticed by the gradual rise of chlorophyll concentrations from St. 5 to 8 , and the close relationship between it and the transparency, in some occasions.

But the grazing effect of the zooplankton on the phytoplankton must also be considered. The composition of the zooplanktonic community in the reservoir, during the period of study, shows that the group that could have exerted larger influence upon the phytoplankton is the Cladocera. Although it is hard to demonstrate this relationship, it is possible that the growth impulse the Cladocera populations presented in the second year had affected the phytoplankton. The larger fall in chlorophyll concentrations, in September, 1970, besides coinciding with a decrease in transparency, coincided also with high population densities of Daphnia gessneri and Bosmina spp.

Sometimes, certain nutrients in high concentrations can inhibit algal growth; Hammer (1969) mentions that a bloom of Anabaena flos-aquae, in Saskatchewan lakes, was inhibited by high concentrations of orthophosphate.

In the reservoir, the influence of toxic substances originating from sewage, and that of the herbicide $2,4 \mathrm{D}$, should also be considered. There is, then, a full range of factors that could have influenced phytoplankton development and only more detailed studies would make evident which of them are the most important.

The composition of the limnetic species of Cladocera in Americana Reservoir, at a given moment, follows the pattern presented by Pennak (1957), i.e., there is one dominant species, one or two that occur in relatively large numbers and finally the remaining species making up a small fraction of the whole. As this author comments, the association of two species of the same genus is rare and when this occurs one of them is at least twenty times more abundant than the other; it is not uncommon, however, the occurrence of more than one species of the genus Ceriodaphnia into the same mass of water. In the reservoir, of the two species 
of Ceriodaphnia-C. cornuta and C. reticulata - of Diaphanosoma - D. sp. and $D$. neotropicum - and of Moina - $M$. sp. and $M$. cf. dubia - the dominants were $C$. cornuta, Diaphanosoma sp., and Moina sp. The dominance of $C$. cornuta regarding $C$. reticulata could be related to the fact that the former is a species restricted to tropical regions (Green, 1972) and, therefore, more adapted to high temperatures. Bosmina longirostris seems to be an indicator of the trophic condition of a water body, and its occurrence in Americana Reservoir could be one of the indications of its eutrophy. Järnefelt (in Rawson, 1956) ascertained that the distribution of $B$. longirostris was restricted to eutrophic Finnish lakes. The replacement of $B$. coregoni by $B$. longirostris, during the eutrophication process, was observed in Lakes Zürich (Minder, in Hasler, 1947) and Washington (Edmondson et al., 1956). In Lake Michigan, Beeton (1965) mentions this replacement, but difficulties with the taxonomy of Bosmina species in this lake, make questionable its relation with eutrophication (Wells, 1970). On the other hand, for Brooks (1969) this relationship is not so evident in many lakes, where predation and in some cases competition might be the important factors. Environmental enrichment, according to this author, would affect indirectly the zooplankton composition, by influence on the populations of planktivorous fish.

In three years, there was a gradual change of dominance from Daphnia gessneri to Diaphanosoma sp.; the total numbers of Cladocera decreased drastically in the third year, after an increase in the second. If the normal course of eutrophication were followed, an increase in their numbers would be expected, or at least its maintenance during this relatively brief time during which apparently no increase in phytoplankton standing crop took place, as already referred. An increase in the numbers of planktonic Crustacea in relation to eutrophication was shown by Bradshaw (1964) in Lakes Erie and Cayuga, and by Patalas (1972) in the Great Lakes. In our reservoir, the larger alterations occurred in St. 5, as may be observed in Fig. 11; in the first two years the numbers of Cladocera were high, decreasing sharply in the third year, including the disappearance of all species in a certain period. In the other two stations, there occurred the disappearance of some species, but never of all at the same time. The reduction in the number of species suggests a selective environment, which could arise from differential predation by fish or from the action of toxic substances on the organisms. Larger species suffer first from predation (Brooks and Dodson, 1965), but as the populations of the smaller species grow, they are themselves used as food, in the absence of the larger ones (Wells, 1970). Unfortunately there are no data about the parallel development of fish populations in the reservoir, except for the known introduction of several species in March, 1972. Even the hypothesis of differential predation would explain only partially what happened in the third year; the disappearance of $D$. gessneri could be explained in that way, for this is a relatively large species, but not the concomitant disappearance of smaller ones such as $C$. cornuta. The dominance of Diaphanosoma sp., in face of fish predation, could reside not in the fact of its being a small species, but in its being an extremely fast swimmer. 
The second hypothesis seems more plausible, and here the effects of toxic substances from sewage and that of the herbicide $2,4 \mathrm{D}$ must be considered.

At the time of the first treatment with the herbicide, there occurred a flood in the region that reached industrial plants, that of Rhodia among others. There are several possible causes for the population decreases after January 28, 1970: the seston enrichment in sediment and consequent troubles to the filtering apparatus of these animals (Pacaud, 1939); washing of the plankton downstream of the dam by the great flow of water; action of toxic substances washed from the flooded industrial plants; and the action of 2,4 D. These causes could hardly be separated, and thus it is not possible to estimate any effect of the herbicide on the Cladocera on this occasion.

According to Crosby and Tucker (1966), 2,4 D seems to be innocuous to Daphnia magna, the $\mathrm{IC}_{50}$ being more than $100 \mathrm{ppm}$. For Daphnia pulex, it was determined that the TLm to the herbicides is $3,2 \mathrm{mg} / 1$ (Commitee Water Pollution Control, 1968). Wojtalik et al. (1971) monitored the effects of DMA 2,4 D used in weed control in two reservoirs in the United States, and concluded that the herbicide had not affected phyto and zooplankton, benthic macroinvertebrates, fishes, and littoral plants; they also observed that the plankton absorbed the herbicide in large amounts, retaining it up to six months after treatment. The authors consider the herbicide to be non-cumulative, what seems contradictory in view of the results. Smith and Isom (1967) detected 2,4 D accumulation in the mud, and in body tissues of mollusks, seemingly without any damage for them; they have also noticed movement of fishes out of the area exposed to treatment. If $2,4 \mathrm{D}$ proves to be cumulative, the possibility exists of toxic thresholds to be exceeded in organisms. The reduction in the number of species and specimens and the non-recovery or slow recovery of the Cladocera populations during the second treatment with $2,4 \mathrm{D}$ in the reservoir seem to point out to an action of the herbicide upon these animals.

A determination made by Rocha et al. (1972), in September, 1971, in Atibaia River and in October of the same year, in Pinheiros and Anhumas Streams, evidenced the occurrence of manganese, copper, zinc, mercury, lead, chromium, cyanide and phenol. Generally these substances were found in the mud and sometimes in the water, but in smaller concentrations. In November, 1971, these authors carried on a survey of toxic substances in Stations 1,2 and 3 of the reservoir, having found in the mud: chromium, mercury, zinc and lead. Chromium and mercury were found, in the reservoir, in higher concentrations than the toxic thresholds for Daphnia magna mentioned in Warnick and Bell (1969). Anderson (1950) compares bioassay results obtained with Daphnia magna and the fish Gasterosteus aculeatus in relation to some heavy metal chlorides. In general, the cladoceran appears to be more sensitive to chlorides than the fish. Among Cladocera, Ceriodaphnia reticulata is more sensitive to zinc than Daphnia magna (Hutchinson, in Anderson, 1950). From the data presented by Warnick and Bell (1969) and Anderson (1950), D. magna is more sensitive to mercury and copper. Phenol, proceeding from Anhu- 
mas and Pinheiros Streams and from Rhodia wastes, probably occurs in the reservoir, although it had not been detected at the moment of the determination. Bioassay carried out with the fish Tilapia sp. and Rhodia wastes, containing phenol, isopropanol and crotaldehyde in unascertained concentrations, resulted in a TLm of 1.5 to $2 \%$. These values are smaller than the concentrations found in Atibaia River downstream of the discharge point, where it is approximately $10 \%$ (Rocha et al., 1972). According to Anderson (1944), D. magna is immobilized at 0,0094 per cent of phenol.

It is possible that, on some occasions, the death of fishes and the depression of Cladocera populations, seemingly withouth explanation, had been caused by toxic substances. However, from the scarcity of data about these substances and the sensitiveness of the organisms to them, it is only possible to suggest that toxic substances have influenced the organisms in the reservoir. As various factors can bring about depressions of Cladocera populations, not always toxic substances can be blamed as their cause. However, when the densities of various species drop at the same time, it is to be expected that they are related to marked environmental changes.

The decrease in numbers of Cladocera at Sts. 5 and 6 during the bloom agrees with observations of Smith (1969) and Smith and Moyle (in Smith, 1969). The probable cause of this decrease is the antagonistic action exerted by substances excreted by the algae when in dense concentrations (Hartman, 1960; Tassigny and Lefèvre, 1971). This action could be direct, by metabolic changes in the animals, or indirect, by inhibiting development of organisms suitable as food. Ryther (1954) observed in the laboratory the inhibitory effect of large concentrations of algae, otherwise suitable as food, on the filtration rate of Daphnia magna. $\mathrm{He}$ also observed that these algae when in a senescent phase inhibited not only the feeding rate, but also reproduction and moulting. The occurrence of large numbers of ephippial females of Daphnia gessneri during the bloom may be an indication of food shortage.

The fall in bottom DO from the second to the third year does not seem to be related to an increase in productivity. The relation between larger productivity and a decrease in deep DO due to eutrophication is a concept developed for relatively small temperate lakes, but that cannot be extended to all water bodies (Beeton and Edmondson, 1972). In tropical lakes temperature is a very important factor, losing the DO its value as indicator of productivity (Ruttner, 1963). The marked decrease in bottom $\mathrm{DO}$ in the third year in Americana Reservoir seems to be due to a larger consumption in decomposition and stabilization processes of mainly allochthonous organic matter.

The periods of thermal stratification in the reservoir seem to have been of short duration. Its relatively small depth and the influence of winds prevent the establishment of seasonal stratification. This lake, according to Hutchinson and Löffler (in Hutchinson, 1957), might be considered as polymictic. In other Brazilian water bodies, such as dams in the Northeast (Wright, 1936 and 1937), Santo Amaro Reservoir (Kleere- 
koper, 1939), and Billings Reservoir (Branco, 1966), seasonal thermal stratification has likewise not been observed, but only short-term stratifications. Of the Amazonian lakes studied by Marlier (1967), one was considered as monomictic, while the others showed homothermy. Short periods of thermal stratification have also been recorded from African lakes (Talling, 1957; Baxter et al., 1965; Robinson and Robinson, 1971) and Indian lakes (Sreenivasan, 1965; Hussainy, 1967).

Presently thermal and DO stratification are being studied in more detail, in Americana Reservoir.

\section{Conclusions}

1 Corroborating the observations made by Rocha et al. (1971 and 1972), self-purification in Americana Reservoir is significant, demonstrated by the decrease in coliform bacteria and ammonia concentrations and the increase in transparency, chlorophyll and superficial DO, from Station 5 to 8 .

2. The concentrations of inorganic $N$ and $P$ increased during the three years of study, probably caused by enlarged afflux of industrial sewage and phosphate-containing detergents, the latter ever more widely used.

3. The decrease of bottom DO concentrations in the third year seems to be related to a larger consumption in processes of decomposition and stabilization of mainly allochthonous organic matter.

4. Thermal stratification seems to have occurred during short periods of time, suggesting the reservoir might be polymictic.

5. There are indications that the phytoplankton did not increase during the three years. Nutrients (inorganic $\mathrm{N}$ and $\mathrm{P}$ ) having not been limiting, it is probable that other factors influenced its development.

6. The observed changes in composition and abundance of the planktonic Cladocera seem to be related to harmful effects of the herbicide $2,4 \mathrm{D}$ and toxic substances originating from sewage.

7 The decrease in numbers of Cladocera, at the time of bloom of the blue-green alga Anabaena spiroides, seem to be related to an antagonistic action of substances excreted by the alga. This action might be direct or indirect through influence upon organisms suitable as food to the Cladocera. The occurrence of relatively large numbers of ephippial females of Daphnia gessneri on that occasion, could be evidence of food scarcity. 


\section{RE F E RE N C E S}

ANDERSON, B. G. - 1944 - The toxicity thresholds of various substances found in industrial wastes as determined by the use of Daphnia magna. Sewage works J., 16 (6) : 1156-1165.

ANDERSON, B. G. - 1950 - The apparent thresholds of toxicity to D. magna for chlorides of various metals when added to Lake Erie water. Amer. Fish. Soc. Trans., 78: $96-113$.

AZEVEDO, P. de; H. KAWAI and J. de O. VAZ - 1967 - Estudo da limnologia e poluição da Represa Rio das Pedras para posterior avaliação da sua produção piscícola. Rev. D.A.E., 66: 48-76.

BAXTER, R. M.; M. V. PROSSER; J. F. TALLING and R. B. WOOD - 1965 - Stratification in tropical African lakes at moderate altitudes (1550 to $2000 \mathrm{~m}$ ). Limnol. Oceanogr., 10: 510-520.

BEETON, A. M. - 1965 - Eutrophication of the St. Lawrence Great Lakes. Limnol. Oceanogr., 10: 240-254.

BEETON, A. M. and W. T. EDMONDSON - 1972 - The eutrophication problem. J. Fish. Res. Bd. Can., 29: 673-682.

BRADSHA'W, A. S. - 1964 - The crustacean zooplankton picture: Lake Erie 1939-49-59; Cayuga 1910-51-61. Verh. Internat. Ver. Limnol., 15: 700-708.

BRANCO, S. M. - 1961 - Biologia das Represas do Alto Cotia. Rev. D.A.E., 22 (4):3-7.

BRANCO, S. M. - 1966 - Estudo das condiçōes sanitárias da Represa Billings. Arq. Fac. Hig. S. Paulo, 20 (1): 57-86.

BRANCO, S. M. - 1971 - Hidrobiologia aplicada ả Engenharia Sanitária. FESB/CETESB, São Paulo, 3 V., 1214 pp.

BROOKS, J. L. - 1969 - Eutrophication and changes in the composition of zooplankton. International Symposium on Eutrophication, Madison, June 11-15, 1967. Nat. Acad. Sci., Washington, D.C., 661 pp.

BROOKS, J. L. and S. I. DODSON - 1965 - Predation, body size and composition of plankton. Science, 150: 28-35.

COMMITEE Water Pollution Control - Water quality criteria - 1968 - Report of the commitee on Fed. Wat. Pollut. Control Fed. Adm. Wash., 234 p.

CROSBY, D. G. and R. K. TUCKER - 1966 - Toxity of aquatic herbicides to Daphnia magna. Science, 154 (3746): 289-291.

DAVIS, C. C. - 1964 - Evidence for the eutrophication of Lake Erie from phytoplankton records. Limnol. Oceanogr., 9 (3): 275-283.

EDMONDSON, W. T. - 1970 - Phosphorus, nitrogen and algae in Lake Washington after diversion of sewage. Science, 169: 690-691.

EDMONDSON, W. T.; G. C. ANDERSON and D. R. PETERSON - 1956 - Artificial eutrophication of Lake Washington. Limnol. Oceanogr., 1 (1): 47-53.

GREEN, J. - 1972 - Freshwater ecology in the Mato Grosso, Central Brazil, II: Associations of Cladocera in meander lakes of the Rio Suiá Missu. J. Nat. Hist., 6 (2) : 215-227. 
HAMMER, V. T. - 1969 - Blue-green algal blooms in Saskatchewan lakes. Verh. Internat. Ver. Limnol., 17: 116-125.

HASLER, A. D. - 1947 - Eutrophication of lakes by domestic drainage. Ecology, 28: 383-395.

HASLER, A. D. and M. E. SWENSON - 1967 - Eutrophication. Science, 158: 278-282.

HARTMAN, R. T. - 1960 - Algae and metabolites of natural waters. The Pymatuning symposia in ecology: The ecology of algae. Spec. Publ. Pymatuning Lab. Fld. Biol., 2: $38-55$.

HUSSAINY, S. V. - 1967 - Studies on the limnology and primary production of a tropical lake. Hydrobiologia, 30 (3/4): 335-352.

HUTCHINSON, G. E. - 1957 - A Treatise on Limnology. 1: Geography, Physics and Chemistry. New York, John Wiley \& Sons, Inc. 1015 pp.

KAWAI, H. and S. M. BRANCO - 1969 - Estudos sobre as relações entre despejos domésticos e industriais da região da Grande São Paulo e a eutrofização do Reservatório Billings. Rev. D.A.E., 71: 1-12.

KAWAI, H.; M. KATO; C. C. AMARAL E SILVA and S. M. BRANCO - 1972 - Eutrofização no lago do Paranoá em Brasílìa. XIII Congr. Interamer. Ingen. Sanit., Paraguay, p. 1-35.

KLEEREKOPER, H. - 1939 - Estudo limnológico da Represa de Santo Amaro em São Paulo. Bol. Fac. Fil. Cienc. Letr., Botânica, 2: 11-151.

MARLIER, G. - 1967 - Ecological studies on some lakes of the Amazon Valley Amazoniana, 1 (2): 91-115.

MARSHALL, B. E. and A. C. FALCONER - 1973 - Eutrophication of a Tropical African Impoundment (Lake McIlwaine, Rhodesia). Hydrobiologia, 43 (1-2): 109-123.

PACAUD, A. - 1939 - Contribution a l'écologie des Cladocères. Bull. Biol. Fr. Belg., Supl., 25: 1-260.

PATALAS, K. - 1972 - Crustacean zooplakton and eutrophication of St. Lawrence Great Lakes. J. Fish. Res. Bd. Can., 29: 1451-1462.

PENNAK, R. W. - 1957 - Species composition of limnetic zooplankton communities. Limnol. Oceanogr., 2 (3): 222-232.

RAWSON, D. S. - 1956 - Algal indicators of trophic lake types. Limnol. Oceanogr., 1 (1): 18-25.

ROBINSON, A. H. and P K. ROBINSON - 1971 - Seasonal distribution of zooplankton in the northern basin of Lake Chad. J. Zool., Lond., 163: 25-61.

ROCHA, A. A. - 1972 - Estudo sobre a fauna bentônica da Represa de Americana no Estado de São Paulo. Dissertação de mestrado, p. 1-65.

ROCHA, A. A.; W. C. BRANCO; H. KAWAI and F. FUKUDA - 1971 - Estudo das condições sanitárias da Represa de Americana. Rev. D.A.E., 31 (79): 369-378.

ROCHA, A. A.; W. C. BRANCO and H. KAWAI - 1972 - Capacidade auto-depuradora da Represa de Americana. XIII Congr. Interamer. Ingen. Sanit., Paraguay, p. 1-27.

RUTTNER, F. - 1963 - Fundamentals of Limnology. University of Toronto Press, 295 pp. 
RYTHER, J. H. - 1954 - Inhibitory effects of phytoplankton upon the feeding of Daphnia magna with reference to growth, reproduction and survival. Ecology, $\mathbf{3 5}$ (4) : 522-533.

SAWYER, C. N. - 1966 - Basic concepts of eutrophication. J. Water Poll. Control. Fed., 38: 739-744.

SCHINDLER, D. W. - 1971 - Carbon, nitrogen and phosphorus and the eutrophication of freshwater lakes. J. Phycol., 7: 321-329.

SCHWOERBEL, J. — 1966 - Methoden der Hydrobiologie. Franckh'sche Verlagshandlung. W. Keller \& Co., Stuttgart. $207 \mathrm{pp}$.

SMITH, G. E. and B. G. ISON - 1967 - Investigation of effects of large-scale applications of 2,4-D on aquatic fauna and water quality. Pestic. Monit. J., 1 (3): 16-21.

SMITH, M. W. - 1969 - Changes in environment and biota of a natural lake after fertilization. J. Fish. Res. Bd. Can., 26 (12): 3101-3132.

SREENIVASAN, A. - 1965 - Limnology of tropical impoundments. III. Limnology and productivity of Amaravathy Reservoir. (Madras State), India. Hydrobiologia, 26: 501-516.

STANDARD Methods for the Examination of Water and Wastewater - 1965 - Am. Publ. Hlth. Assoc. Am. Wat. Ass., Wat. Pollut. Control Fed., 12th ed., New York, 769 p.

STANDARD Methods for the Examination of Water and Wastewater - 1971 - Am. Publ. Hlth. Assoc. Am. Wat. Ass. Wat. Pollut. Control, Fed., 13th ed., New York, 874 p.

STEWART, K. M. and G. A. ROHLICH - 1967 - Eutrophication: a review. Publication n. 34, State Water Quality Control Board, State of California, $188 \mathrm{p}$.

TALliNG, J. F. - 1957 - Diurnal changes of stratification and photosynthesis in some tropical African waters. Proc. Roy. Soc., London, 147s 57-83.

TASSIGNY, M. and M. LEFEVRE - 1971 - Auto, hétéroantagonisme et autres conséquences des excrétions d'algues d'eau douce ou thermale. Mitt. Internat. Ver. Limnol., 19: 26-38.

VERDUIN, J. - 1954 - Phytoplankton and turbidity in Western Lake Erie. Ecology, 35 (4): $550-561$.

WARNICK, S. L. and H. L. BELL - 1969 - The acute toxicity of some heavy metals to different species of aquatic insects. J. water Poll. Control Fed., 41 (2): part 1: 280-284.

WELLS, L. - 1970 - Effects of alewife predation on zooplankton population in Lake Michigan. Limnol. Oceanogr., 15 (4): 556-565.

WOJTALIK, T. A.; T. F. HALL and L. O. HILL - 1971 - Monitoring ecological conditions associated with wide scale application of DMA 2,4-D to aquatic environments. Pestic. Monit. J., 4 (4): 184-203.

WRIGHT, S. - 1936 - Thermal conditions in some waters of Northeast Brazil. An. Acad. Bras. Cienc., 8 (3): 163-173, Rio de Janeiro.

WRIGHT, S. - 1937 - Chemical conditions in some waters of Northeast Brazil, IV. An. Acad. Bras. Cienc., 9 (4): 277-306, Rio de Janeiro.

ZARET, T. M. - 1969 - Predation-balanced polymorphism of Ceriodaphnia cornuta Sars. Limnol. Oceanogr., 14 (2): 301-303. 
